\author{
Ks. JANusz WycisLo
}

\title{
POLSKIE WYDAWNICTWA PRASOWE W PIEKARACH POD BYTOMIEM W LATACH 1847-1939
}

Piekary na Górnym Śląsku, znane głównie z sanktuarium maryjnego wybudowanego $\mathrm{z}$ małych ofiar niezliczonej rzeszy biednych ludzi i specyficznej tradycji wywodzącej swój wyjątkowy status ze ścisłych związków tego ośrodka sakralnego z ludźmi ciężkiej "pracy, odegrały w latach 1847-1939 ważną rolę jako jeden z pierwszych i prężniejszych ośrodków prasy polskiej na Górnym Śląsku.

Pierwsza oficyna wydawnicza w Niemieckich Piekarach założona przez T. Heneczka $\mathrm{z}$ inspiracji i z pomocą finansową ks. J. Ficka, od chwili powstania w $1847 \mathrm{r}$. mieściła się w nurcie teoretycznych i praktycznych działań, istotnym dla tożsamości narodowo-religijnej społeczeństwa tego regionu oraz jego celów oświatowo-kulturalnych, pogłębiających polską i katolicką działalność społeczną na Górnym Śląsku.

W ciągu prawie stuletniej działalności kilku różnych oficyn wydawniczych w Piekarach pod Bytomiem realizowano w nich zawsze przynajmniej jedno $z$ dwóch głównych haseł pioniera katolicyzmu społecznego na Śląsku, kustosza sanktuarium maryjnego w latach 1826-1862, ks. J. Ficka, które brzmiały: „Nie jest obrońcą ludu gómośląskiego ten, kto nie broni i nie utrzymuje języka ojczystego polskiego ludu tutejszego" oraz „Dopóki język polski będzie rozbrzmiewał na Górnym Śląsku, dopóty wiara święta zostanie w w sercach ludu"2. Konsekwentnie hasła proboszcza z Niemieckich Piekar, zwanego „Apostołem Śląska”, powtarzały kolejne pokolenia nie tylko mieszkańców tego regionu. Dzięki temu prasowe ośrodki wydawnicze w Piekarach mogły ,łatwiej” oddziaływać na kształt życia jednostki, rodziny i społeczeństwa, utrwalać odrębność kulturową polskiej ludności na Górnym Śląsku, stanowiącą jeden z najważniejszych czynników społecznych tego regionu. Należy bowiem pamiętać, że na płaszczyźnie kultury duchowej prowadzona była najbardziej zdecydowana i nieustępliwa walka o zniszczenie jej polskiej tożsamo-

" „Głos z nad Brynicy" [dalej GB] $1925 \mathrm{nr} 15 \mathrm{z}$ dn. 16. 06.

? GB 1925, nr 24 z dn.19.09. 
ści. Dlatego już od Wiosny Ludów ośrodek piekarski, publikujący głównie druki religijne i pobożnościowe, służył uświadomieniu etnicznemu, a potem narodowemu Górnoślązaków, którzy kształtowali swe postawy narodowe, opierając się na relacjach do języka polskiego uznawanego za sacrum.

Cechą nadrzędną wielu czasopism polskich ukazujących się nie tylko w Niemieckich Piekarach, lecz na całym Górnym Śląsku, traktowanym przez Niemców do 1921 r. jako integralna część dziedzictwa niemieckiej Rzeszy, było świadome kształtowane aspiracji narodowych Polaków, pozostających w oczywistej sprzeczności z lojalną postawą obywateli wobec państwa prusko-niemieckiego realizującego agresywną Ostpolitik. Chociaż czasopisma z Niemieckich Piekar (potem Wielkich Piekar) nie miały szerokiego zasięgu, niektóre $\mathrm{z}$ nich przekraczały w XIX w. granice zaborów. Wywierały zatem pewien wpływ na aktywizację narodowo-religijną ludności nie tylko Górnego Śląska, doprowadzając pod koniec XIX w. do usamodzielnienia się - chociaż niezupełnego - ludności polskiej od polityki partii Centrum.

$\mathrm{W}$ połowie lat 20. XX w., w zmienionej sytuacji politycznej i narodowej, Piekary stały się - obok Bielska, Cieszyna i Tarnowskich Gór - najruchliwszym ośrodkiem prasowym. Niektóre $\mathrm{z}$ czasopism związanych $\mathrm{z}$ tym miejscem pielgrzymkowym pogłębiały świadomość religijną, a także kształtowały i rozwijały polskie postawy narodowe, czego dowodem może być zaangażowanie wielu polskich mieszkańców Górnego Śląska w czasie powstań ludowych i plebiscytu.

\section{1. „DZIENNIK GÓRNOŚLA S K I”}

Pierwszym propolskim czasopismem o formacie zbliżonym do A4, wydawanym w ówczesnej południowo-wschodniej części rejencji opolskiej, tj. w powiecie bytomskim, był „Dziennik Górnośląski”, ukazujący się najprawdopodobniej od czerwca $1848 \mathrm{r}$. do października $1849 \mathrm{r}^{3}$ Najpierw drukowano go na ćwiartce arkusza złożonego w Niemieckich Piekarach ${ }^{4}$, w oficynie wydawniczej T. Heneczka, który wcześniej pracował jako drukarz w klasztorze Ojców Paulinów na Jasnej Górze w Częstochowie. Stamtąd jednak za pośrednictwem wikarego ks. D. Mastalskiego, współpracownika najbardziej znanego wówczas w diecezji wrocławskiej proboszcza ks. J. Ficka, Heneczek został sprowadzony do znanej śląskiej miejscowości pielgrzymkowej ${ }^{6}$. Poczatkowo „Dziennik Górnośląski” wychodził dwa razy

\footnotetext{
${ }^{3}$ Wiadomo, że ukazało się 100 numerów tego czasopisma, ale pierwsze 10 numerów zupełnie zaginęło.

${ }^{4} \mathrm{~W}$ literaturze przedmiotu problem ten dokładnie opisał F. A. Marek, Najdawniejsze czasopisma polskie na Ślqsku 1789-1854. Wrocław-Opole 1972, s. 80-113.

${ }^{3}$ Osoba T. Heneczka jako poddanego rosyjskiego (dopiero od 5 lat mieszkającego na Śląsku pruskim) nie budziła zaufania pruskiej administracji, a szczególnie władz cenzorskich. Dlatego ks. Ficek zmuszony zostal do użycia podstępu. Wobec władz rejencji opolskicj jako właściciela drukarni przedstawił swego powinowatego Józefa Heera, zajmującego stanowisko generalnego pełnomocnika majątków państwa pruskiego na Śąsku.

' J. Kudera, Dziennikarstwo polskie na Ślasku. Zarys historyczny, Bytom 1912, s. 33; J. Saratowicz-Stolarzow ic zowa, Teador Heneczek: Górnoślaski drukarz - redaktor-wydawca. Katowice 1985, s. 10.
} 
w tygodniu (w środy i soboty). Jego profil był oparty na narodowych tradycjach i kulturze polskiej, głoszonych przez demokratów polskich. Wydawcom i redaktorom nie chodziło o artyzm językowy, ale o niesłychanie ważną funkcję społeczno oświatową i edukacyjną prasy polskiej. Odtąd chłop, rzadziej robotnik, zamiast iść do karczmy, mógł spędzić czas na pożytecznej lekturze, równocześnie ucząc się dyskusji. Redakcję „Dziennika Górnośląskiego” tworzyli: działacz narodowy i inicjator zakładania polskich instytucji kulturalno-oświatowych J. Mierowski, nauczyciel i pisarz E. Smołka, znany $z$ energii i wielu niezwykłych wówczas inicjatyw społecznych proboszcz bytomski ks. J. Szafranek, zwany „czerwonym farorzem”, pionier budzenia ducha narodowego na Śląsku J. Lompa oraz późniejszy profesor Uniwersytetu Jagiellońskiego J. Lepkowski ${ }^{8}$. Chociaż szata graficzna czterostronicowego pisma była skromna - tytuł ujęty został w dwuwiersz, tekst dwuszpaltowy był lamany ręcznie - redaktorzy potrafili zainteresować ok. 200 prenumeratorów literaturą i kulturą polską, walką o język polski ${ }^{9}$ i podmiotowe prawa osoby ludzkiej, co stanowiło novum wyprzedzające epokę. Pismo, zdaniem prasoznawców, docierało jednak nie tylko do prenumeratorów, lecz do znacznie szerszego grona czytelników, liczącego co najmniej kilkanaście tysięcy. Było bowiem pierwszym radykalnym w poglądach pismem polskim propagującym koniecznośc rewolucji narodowej i społecznej. Czasopismo demaskowało pruską politykę germanizacyjną, ale potrafiło odróżnić ją od społeczeństwa niemieckiego, które po cześci było przychylne Polakom. „Dziennik Gómośląski” cytował wypowiedzi nawet tych Niemców, którzy przypominali krzywdzące Polaków decyzje polityczne administracji pruskiej.

Ponieważ ks. Ficek zamierzał posłużyć się tym nowym medium komunikacji społecznej dla celów stricte ewangelizacyjnych, bacznie przypatrywał się zespołowi redakcyjnemu i jego pracy. Kiedy więc radykalizm narodowo-polityczny „Dziennika Górnośląskiego" wzbudził jego wyraźny niepokój natury religijnej, 28.10.1848 roku redakcję „Dziennika Górnośląskiego” przeniesiono z Niemieckich Piekar do pobliskiego Bytomia (do folwarku na Piłkowie), gdzie - prawdopodobnie bez wiedzy biskupa wrocławskiego - gościny udzielił jej ks. J. Szafranek, znany z wielkiej odwagi cywilnej nie tylko na polu politycznym, ale także w zakresie działań duszpasterskich. $Z$ tego właśnie powodu po krótkim czasie czasopismo zaczęto tłoczyć $\mathrm{u}$ K. Kirscha jako organ wydawniczy Klubu Narodowego ${ }^{10}$. Sprawom rozbudzania życia narodowego Ślązaków miało służyć, powołane przy redakcji czasopisma Towarzystwo Pracujących dla Oświaty Ludu Górnośląskiego ${ }^{11}$. Dzięki tej organizacji

\footnotetext{
${ }^{7}$ J. Wycisło, Józef Szafranek (1807-1874), Ksiqdz, pedagog, dzialacz narodowy, krzewiciel kultury $i$ oświaty. Katowice 1990.

${ }^{8}$ R. Śmiela, Dzienik Górnoślaski 1848-1849. Katowice 1957, s. 18. Jako ostatni redaktor „Dziennika..." J. Lepkowski został wydalony przez pruskie władze polityczne w połowie lipca $1849 \mathrm{r}$.

${ }^{9}$ W. Ogrodziński, Dzieje piśmiennictwa ślaskiego, Katowice 1965, s. 113-114.

${ }^{10}$ A. Rombowski, Dziennik Górnoślaski 1848-1849, „Sobótka” 1948, z. 3, s. 212-223.

${ }^{11}$ M. Kalczyńska, Wydawnictwo prasowe „Gazety Opolskiej" w roli edytora i popularyzatora ksiażki polskiej w Opolu (1890-1923). Opole 1994, s. 20-21.
} 
wokół redakcji skupił się ruch kulturalno-oświatowy Górnego Śląska, a po czasopismo sięgnęło zapewne znacznie więcej osób. Zarówno „Dziennik Górnośląski” jak i Towarzystwo... opowiadały się za dosyć naiwną demokracją, ich zdaniem demokrata to po prostu przyjaciel ludu. Również do działań parlamentarnych odnoszono się $\mathrm{z}$ rezerwą, za to przychylnie oceniano dążenia rewolucyjne. Mocnym atutem „Dziennika Górnośląskiego" były krótkie, ale rzetelne i celnie wybrane informacje poszerzające zasób wiedzy czytelników. Wdrażały do podniesienia świadomości narodowej, broniły kultury polskiej, podkreślały wagę posługiwania się językiem ojczystym, tj. polskim, uczyły szacunku do historii Śląska i Polski, wskazując na wspólne korzenie wszystkich Górnoślązaków. O tym niegdyś piekarskim czasopiśmie taki sąd wyraził opiniotwórczy „Przegląd Poznański”: „[«Dziennik Górnośląski»] wyraźnie wpływ pism wychodzących w Księstwie Poznańskim przyjmował, przedrukowywał artykuły $z$ "Wielkopolanina», rozpisywał się o Lidze [Polskiej], popierał też w każdym czasie sprawy radykalnego stronnictwa na Śląsku i w Berlinie (do którego należał ks. Szafranek, proboszcz z Bytomia); co się zaś tyczy rzeczy religijnych, albo je pomijał, albo je traktował z góry i bez przychylności"12. Niemniej jednak zdaniem redaktorów „Dziennika Górnośląskiego”, religia stanowiła znaczący czynnik wychowywania społeczeństwa w duchu patriotyzmu. Wszak katolicy stanowili olbrzymią część społeczeństwa zainteresowanego tą gazetą. W okresie największej aktywności politycznej „Dziennik Górnośląski” mógł „docierać" do czytelników liczących nawet od kilku do kilkunastu tysięcy osób, jako że na Górnym Śląsku polską prasę zwyczajowo czytano w gronie rodziny wielopokoleniowej i sąsiadó ${ }^{13}$. Trudności finansowe sprawiły, iż pismo to upadło w połowie lipca $1849 \mathrm{r}^{14}$, co nastąpiło nagle i niespodziewanie. Roli „Dziennika Górnośląskiego" nie można przecenić zważywszy, że od numeru 41. z 1848 r. czasopismo to ciągle podkreślało - co stwierdził F. Marek - że „Ślązak zawsze stanowił synonim Polaka". $Z$ wielu powodów gazeta napotykała na różnego rodzaju przeszkody: odmawiano przyjmowania abonamentu, nie dostarczano kolejnych egzemplarzy pisma, prowadzono nagonki, ośmieszano treść artykułów i samych redaktorów. Te działania stanowiły ,żelazny" kanon walki Niemców i ich różnorodnych agend administracyjnych $\mathrm{z}$ polskimi czasopismami. Wrogie czasopismu były ataki prasy niemieckiej, szczególnie zaś napaści „Schlesische Zeitung” nie cofające się przed przekłamaniami i oszczerstwami.

12 „Przeglad Poznański”" 1849, t. 9, s. 630.

${ }^{13}$ Prasoznawcy uwaźają, iż liczba czytelników mogła dochodzić nawet do 20 tys. osób. Zob. J. Glensk, Naklady prasy polskiej na Śląsku (1789-1939), , Studia Śląskie” [Opole] 1978, t. 30, s. 140 n.; A. Mendykowa, Dzieje ksiqżki polskiej na Ślasku. Wrocław 1991, s. 387.

${ }^{14}$ T. Cieślak, Prasa polska na Śląsku, Pomorzu i Mazurach w latach 1832-1870, [w:] Prasa polska w latach 1661-1864, red. J. Lojek, Warszawa 1976, s. 263-264. 


\section{2. "TYGODNIK KATOLICKI. PISMO TOWARZYSTWA MARYAŃSKIEGO"}

To pierwsze na Górnym Śląsku, niedocenione po dziś dzień nie tylko przez część prasoznawców, czasopismo religijne, będące organem wydawniczym założonego 17.09. 1848 r. w Niemieckich Piekarach Towarzystwa Mariańskiego ${ }^{15}$, które zaczęło się ukazywać dosyć regularnie od 7.10. 1848 r., tj. po zniesieniu cenzury i wielu przepisów zakazujących publikowania tematyki religijnej $\mathrm{Z}$ tego powodu często nazywano je „Tygodnikiem Mariańskim”, co w literarurze przedmiotu już pod koniec XIX w. spowodowało sporo zamieszania ${ }^{16}$. Nakładcą i formalnym redaktorem pisma był ks. J. Ficek, proboszcz piekarski, który mimo wielu dręczących go chorób był niezmordowany w podejmowaniu kolejnych wysiłków, wykorzystując zaś nowy środek masowego przekazu - czasopismo - zainicjował nową wówczas metodę pozyskiwania świeckich zaangażowanych apostolsko. Piekarski proboszcz jako jeden z pierwszych duchownych katolickich największej wówczas w Europie diecezji wrocławskiej ,przeznaczył ten środek masowego przekazu nie tyle na potrzeby informacji (głównie społeczno - politycznej ${ }^{17}$ ), ile formacji religijno-moralnej jednostki ludzkiej. W sposób zasadniczy odnosiło się to do zaangażowanych apostolskó świeckich. Podobnie uczynił wcześniej, w 1842 r., a więc w okresie wzmożonego prześladowania polskich mieszkańców Śląska ${ }^{18}$, powodowany duszpasterskim obowiązkiem, a nie „dbaniem o rozgłos” - wydając własnym nakładem u ojców Mechitarzystów w Wiedniu dzieło ks. P. Skargi Żywoty Świętych Starego i Nowego Zakonu ${ }^{19}$, a kilka lat później - znakomity podręcznik historii Polski i Kościoła w Polsce, a zarazem specyficzny elementarz ascetyczny i pedagogiczny F. Jaroszewicza pt. Matka Świętych Polska, albo Żywoty świętych, blogoslawionych, wielebnych, świątobliwych, pobożnych Polaków i Polek, z różnych autorów i pism zebrane i spisane, do druku podane r. 1767, teraz przedrukowane. Oba dzieła charakteryzowały wartości katolickie i polskie pozostające w symbiozie, stanowiące dziedzictwo pokoleń polskich mieszkańców Górnego Śląska. Podobnie miała się sprawa z „Tygodnikiem Katolickim”. Faktycznymi redaktorami „Tygodnika Katolickiego” byli prawdopodobnie mieszkający w charak-

is Jego celem były: „obrona świętej wiary katolickiej”, „pomnożenie gorliwości w zachowaniu przykazań Boskich”, „ćwiczenie się w cnotach i dobrych uczynkach”, które miały zneutralizować dechrystianizację społeczeństwa, wynikającą pośrednio z gwałtownej industrializacji i urbanizacji regionu przemysłowego.

${ }^{16}$ Skutkiem zamieszania było mniemanie niektórych redaktorów (czasopism polskich i niemieckich), a także dziejopisarzy, że istnieje inne niż „Tygodnik Katolicki” czasopismo piekarskie - właśnie pt. „Tygodnik Mariański". Zob. np. J. Kudera, Obrazy Slazaków wspomnienia godnych. Mikołów 1920, s. 18.

${ }^{17}$ Dla niektórych współczesnych prasoznawców brak tej tematyki w czasopiśmie ks. Ficka stanowi poważny zarzut.

${ }^{18}$ M. Pater, Polska i katolicka tożsamość Górnego Śląska w perspektywie historycznej XIX wieku, [w:] Metropolia katowicka - górnośląska. Dziedzictwo historii. Wyzwania wobec przyszlości, red. W. Świątkiewicz, J. Wycisło, Katowice 1994, s. 46-48.

${ }^{19}$ Cz. 1, s. 680 , cz. 2, s. 649 , ndl. 84 . 
terze gości na probostwie dwaj jezuici krakowscy: I. Czeżowicz i A. Peterek ${ }^{20}$. Ze względów politycznych w czasopiśmie jako drukarza podawano nazwisko powinowatego proboszcza z Piekar - J. Heera, który piastował stanowisko generalnego pełnomocnika majątków państwa pruskiego na Górnym Śląsku, lecz wiadomo było, że za jego nazwiskiem krył się T. Heneczek. „Tygodnik Katolicki” nie opublikował żadnego artykuhu programowego, a jedynie sprawozdanie z pierwszego posiedzenia ponadparafialnego - co wówczas stanowilo novum - Towarzystwa Mariańskiego, którego celem było pogłębienie świadomości religijnej mieszkańców Gómego Śląska, w myśl przekonania katolickich działaczy społecznych o jej niezbędności w przeprowadzaniu każdej reformy społecznej. W miejscowości pielgrzymkowej egzemplarz pisma kosztował 7 srebrnych groszy i 6 fenigów, na poczcie zaś - 9 srebrnych groszy i 6 fenigów. Można też było zakupić pismo w Krakowie, w znanej księgarni J. Wildta, która sprzedawała nowości zarówno polskie, jak i obce, nuty i mapy, ryciny i podobizny znanych Polaków, a także powieści historyczne, podróżnicze, a nawet sensacyjne ${ }^{21}$. Wbrew powielanym opiniom pojawiającym się nawet w literaturze naukowej, czasopismo to nie miało charakteru niemieckiego ${ }^{22}$. Otwierało nowy etap katolickiej działalności religijno - społecznej na Górnym Śląskz i było wpisane w powstały na zachodzie Europy tzw. katolicyzm społeczny ${ }^{23}$. Sprzeciwiało się różnego rodzaju tendencjom separatystycznym, traktując religię jako dar Boży i część wielkiej spuścizny narodowej. Dzięki „Tygodnikowi Katolickiemu" realnie poszerzył się krąg świeckich zaangażowanych apostolsko. Znamy nazwiska niektórych mieszkańców Niemieckich Piekar i okolicy, którzy wyrazili chęć bliższej współpracy z proboszczem, stając się tym samym aktywną elitą ${ }^{24}$. Grupa ta, opierając się na lekturze czasopisma, podjęła pracę w celu uporządkowania życia religijno-społecznego, a więc i kulturowo-narodowego. Współpracowała nie tylko z proboszczem, ale także $\mathrm{z}$ innymi plebanami, głównie okręgu poddanego gwałtownej industrializacji ${ }^{25}$. Wielu innych duchownych żywo zainteresowanych piekarskim czasopismem zwracało się do ks. Ficka z prośbą o umożliwienie druku posiadanych przez nich manuskryptów. Byli to m.in.: ks. Blasel w miejscowości Walce, wikariusz Wodziński z Białej [k. Bielska], ks. Klajner z Dubina k. Jutrosina, duchowni diecezjalni i zakonni z Warszawy, Pilicy, Wielkich Strzelec, którzy w ten sposób pragnęli propagować misję ewangelizacyjną. Przekonała ich bowiem nie tylko ciekawa redakcja pisma, ale także sposób, w jaki

\footnotetext{
${ }^{20} \mathrm{~W}$ literaturze przedmiotu często mylnie podaje się inne nazwiska redaktorów jezuitów.

${ }^{21}$ G. Schmager, Wildt Juliusz, [w:] Słownik pracowników ksiażki polskiej, Warszawa-Łódź 1972, s. 959-960.

22 D. Sicradzka, A. Żydek, Z kart gazet piekarskich, [b.m.w.] 1995, s. 23.

${ }_{23} \mathrm{~J}$. Wycisło, Sanktuarium Matki Bożej w Piekarach Ślq̨skich, t. 1: Formowanie się glównego ośrodka życia religijno-spolecznego na Górnym Ślqasku w XIX wieku. Katowice 1991, s. 261.

${ }^{24}$ Byli to m.in.: Langer, Sperling, Maciołowicz, Kipiński, J. i M. Spyrowie, W. Czypionka, J. Małota i ok. 80 innych.

${ }^{25}$ Ks. B. Purkopem z Woźnik, ks. A. Stabikiem z Michałkowic, L. Markiewką z Bogucic, ks. K. Klose $\mathrm{z}$ Wielkiego Żyglina oraz ks. C. Scheunem - plebanem z Kamienia.
} 
drukowano „Tygodnik Katolicki”. Był on czasopismem jednokolumnowym, powielanym w „poręcznym" małym formacie $(20 \times 13 \mathrm{~cm})$ liczącym osiem stron. Jego zaletą była także stosunkwo niska cena. Walory czasopisma piekarskiego wzrosły po upadku w pewnym sensie opozycyjnego wobec niego „Dziennika Górnośląskiego", gdy to w czasopiśmie ks. Ficka zaczął ukazywać się cykl artykułów autorstwa charyzmatycznego jezuity K. Antoniewicza-Bołoza pt. Listy z Krakowa, a później Groby Świętych Pańskich. One to bowiem umacniały dumę narodową Polaków, niosły pociechę i nadzieję na odzyskanie niepodległości przez Polskę ${ }^{26}$. Lektura tych artykułów cieszyła się wielką popularnością. Niewątpliwie wywierała ogromny wpływ na zainteresowanie dawną stolicą Polski, jej bogatą tradycją narodową i świetnością kultury intelektualno-materialnej. Przyczyniała się też do ożywienia tzw. pielgrzymek narodowych do Krakowa ${ }^{27}$, które stały się niezwykle popularne, stanowiąc m.in. niezwykłą lekcję chwalebnej historii Polski. Z kolei inni, nie mniej popularni autorzy artykułów zamieszczanych na łamach „Tygodnika Katolickiego", jak np. znawca kultury ludowej i autor dziełek religijnych ks. J. Laxy czy proboszcz z pobliskich Michałkowic ks. A. Stabik, propagowali umiłowanie języka polskiego i tradycji ojców oraz podtrzymywanie więzi duchowej z Polską. Analiza treści zackowanego po dziś dzień zbioru 64 egzemplarzy ${ }^{28}$ organu wydawniczego Towarzystwa Mariańskiego, który zdaniem F. Marka trzykrotnie zmieniał ideowe oblicze, pozwala sądzić, że ks. Ficek podstawę formacji osadził na chrześcijańskiej caritas, podkreślając, iż jest to ostateczny fundament właściwego funkcjonowania każdego społeczeństwa.

Współcześni prasoznawcy oceniają, iż wysokość nakładu „Tygodnika...” wynosiła 100 egzemplarzy, ale już w kontekście przytoczonych wywodów wydaje się, iż jest to liczba zaniżona. Pewne przesłanki, w postaci zachowanych kilkudzięsieciu listów skierowanych do ks. Ficka, pozwalają twierdzić, że zakupu czasopisma dokonywano także w samej drukarni, a głównie na probostwie, gdzie poszukiwano też jego archiwalnych egzemplarzy. Liczna korespondencja kierowana do proboszcza w Niemieckich Piekarach stanowi również dowód na to, iż nawet 11 lat po zaprzestaniu drukowania „Tygodnika...” poszukiwano kompletu tego czasopisma w Warszawie oraz w szpitalu o charakterze hospicjum w pewnym mieście powiatowym. Część prasoznawców wiąże upadek „Tygodnika Katolickiego” z bojkotem prasy polskiej przez pruskie urzędy pocztowe lub $z$ celowym niedoręczaniem jego egzemplarzy stałym abonentom (było ich niewielu $-97 \mathrm{w} 1849 \mathrm{r}$.) ${ }^{29}$ ze względów politycznych. Z przeprowadzonych badań wynika jednak, iż likwidacja „Tygodnika..." związana była raczej z nałożeniem na niego wysokiej kaucji, władze pruskie uznały bowiem, że artykuły czasopisma pełniącego funkcję nowego środka misji

\footnotetext{
${ }^{26}$ F. A. Marek, Najdawniejsze czasopisma polskie..., s. 114-139.

${ }^{27}$ J. Kwiatek, Związki Górnego Śląska z Galicja na przelomie XIX i XX wieku, Opole 1994.

${ }^{28} \mathrm{Tj} .512$ stron druku w języku polskim.

${ }^{29}$ Najwięcej abonentów było w: Opolu, Reptach, Koźlu - po 9, Katowicach - 8, Oleśnie - 5 .
} 
ewangelizacyjnej Kościoła mają charakter polityczny, a więc zagrażają imperialistycznej polityce pruskiej. Wobec tego kierownik Wydziału Spraw Wewnętrznych w Urzędzie Rejencyjnym w Opolu listem z 19.07. 1850 r. powiadomił o tym ks. Ficka i tym samym doprowadził do likwidacji czasopisma ${ }^{30}$.

\section{3. „ZW I ASTUN GÓRNOŚLĄSKI. \\ PISMO POŚWIĘCONE WIADOMOŚCIOM RELIGIJNYM I POLITYCZNYM"}

Początek kolejnego etapu rozwoju prasy polskiej na Górnym Śląsku, tak ważnego dla dalszej popularyzacji ośrodka wydawniczego w miejscowości pielgrzymkowej, wytyczył nowy tygodnik polityczno-religijny - „Zwiastun Górnośląski”31, wydawany w Niemieckich Piekarach od 31.01.1868 r. do 26.12.1872 r. przez drukarza T. Heneczka ${ }^{32}$. Był to polski organ Katolickiego Związku Ludowego (Katholisches Volksverein), będący obiektem szczególnej troski pastoralnej i społecznej bpa Adriana Włodarskiego. Z uwagi na to, że następcą ks. J. Ficka w słynnej miejscowości pielgrzymkowej został ks. B. Purkop, który wcześniej zamieszczał swe artykuły (głównie dotyczące sprawy wstrzemięźliwości od tzw. napojów palonych, tj. alkoholu) we wrocławskim „Schlesisches Kirchenblatt”, bp. A. Włodarski nakłonił go do kierowania „Zwiastunem...” ${ }^{33}$. Pismo ukazywało się w dużym formacie, liczyło 8 stron wyraźnego, dwuszpaltowego druku. Oprócz ozdobnej winiety zawierającej inicjal Maryi na tle szarfy, krzyża i gwiazdy (symboli Stwórcy), które promieniowaly ,na wszystkie strony świata”, pismo nie zawierało, $z$ dwoma wyjątkami, żadnych ilustracji. W myśl założeń programowych, czasopismo miało zamieszczać artykuły dotyczące Kościoła katolickiego, wyjaśnienia katechizmowe i wiadomości religijne, a także zagadnienia polityczne oraz „wiadomości gospodarcze, industryjne, astronomiczne i różne należące do domowych potrzeb, na koniec [zaś] literaturę i kronikę, i prywatne doniesienia" ${ }^{\text {"3 }}$. Wbrew zapowiedziom redakcji treść „Zwiastuna...” była uboga, nieciekawa, ułożona schematycznie. Po artykule wprowadzającym umieszczano krótsze, o treści religijnej, opisy miejsc świętych, rozmaitości ze świata i wskazania służące formacji duchowej czytelnika. Wiele artykułów ukazywało bolączki życia religijno-społecznego, jak: laicyzację życia, rosnące wpływy społeczno-polityczne protestantyzmu, przekraczanie przykazań Bo-

${ }^{30}$ Archiwum Parafii św. Bartłomieja Ap. i Imienia Matki Bożej w Piekarach, List nr 42, rkp., bez sygn.

${ }^{31}$ Nazwa czasopisma miała „zwiastować lepszą przyszłość ludowi ṡląskiemu”.

${ }^{32}$ A. Masarczyk, Poglądy na Kościól wystepujące na Ślasku na podstawie „Zwiastuna Górnoślqskiego" (1868-1872), „Śląskie Studia Historyczno-Teologiczne” t. 15, Katowice 1982, s. 91-92; Polskie czasopisma religijno-spoleczne w XIX wieku. Materialy do katalogu, red. D. Olszewski i in., Warszawa-Lublin 1988, s. 811, nr 1081.

${ }^{33}$ M. Pater, Stosunki polityczne, [w:] Historia Ślqska, t. 3: 1850-1918, cz. 1: 1850-1890, red. S. Michalkiewicz, Wrocław-Warszawa-Kraków-Gdańsk 1976, s. 281.

${ }^{34}$ „Zwiastun Gómośląski” [dalej: ZG] 1868, nr 1. 
żych, szczególnie w wyniku kradzieży, pijaństwa, rzadziej brak troski o większą spójność rodziny i brak dawania dobrego przykładu młodszemu pokoleniu. Treści „Zwiastuna...", w zamierzeniu redakcji, miały uzupełniać posługę słowa zasłyszanego $\mathrm{z}$ ambony i stanowić instrument służący pogłębianiu świadomości wiary $\mathrm{i}$ odpowiedzialności za Kościół powszechny. Egzemplarz pisma, w cenie 9 srebrnych groszy i 9 fenigów, nie był jednak atrakcyjny, ponieważ nie uwzględniał innych aktualnych i egzystencjalnych informacji niezbędnych czytelnikom. Ponadto zasadniczy program „Zwiastuna...” przesadnie podkreślał też lojalność wobec króla i rządu pruskiego. Dopiero zatrudnienie $\mathrm{w}$ redakcji dotychczasowego nauczyciela $\mathrm{K}$. Miarki, który radykalnie zmienił profil ideowy czasopisma na ciekawszy i bardziej przystępny dla czytelnika, doprowadziło do rozwoju gazety ${ }^{35}$. Omawiając na jej łamach aktualności polityczno - społeczne i religijne oraz przedstawiając zagrożenie Kościoła katolickiego ze strony wrogich potęg, zagrożenie egzystencji materialnej papieża, sprawy państwa kościelnego itp., Miarka zdobył dla „Zwiastuna...” wielu nowych abonentów. W 1869 r. było ich już ponad 3000, co na ówczesne warunki górnośląskie stanowiło liczbę rekordową. Najwięcej egzemplarzy „Zwiastuna..." trafiało do rąk czytelników Królewskiej Huty [dziś: Chorzowa] - 256, Siemianowic - 56, Bytomia 40, tabęd pod Gliwicami - 37, Niemieckich Piekar 36. Około 150 duchownych aktywnie właczyło się w stały kolportaż pisma ${ }^{36}$. Karol Miarka zaprosił też do współpracy wielu znakomitych reprezentantów ruchu kulturalno - oświatowego Górnego Śląska: ks. N. Bonczyka z Bytomia, autora prawie zapomnianych dziś dwóch epopei śląskich, J. Ligonia z Królewskiej Huty, ks. J. Kuhna z Gliwic oraz ks. A. Stabika z Michałkowic. K. Miarka umożliwił też debiut literacki tzw. samorodnym pisarzom ludowym: Wawrzyńcowi Hajdzie, zwanemu „Wernyhorą Śląskim”, i D. Szendzielorzowi ${ }^{37}$. Poza korespondentami duchownymi, ze „Zwiastunem...” współpracowali również nauczyciele uwzględniający w jego publicystyce informacje ze Śląska. Ważną częścią programu gazety była wówczas walka o język polski, szczególnie w szkolnictwie. Przy redakcji założono polską księgarnię i czytelnię oraz serię „Wydawnictwo Katolickie Dobrych a Tanich Książęk", rozwijające się pomyśnie dzięki dobrym kontaktom członków redakcji z duchowieństwem i ludowymi pisarzami śląskimi, co podkreśla literatura naukowa. Inicjatywa drukowania tej serii była pomysłem na wielką skalę. Zamierzano bowiem przyjmować do druku dzieła literatury polskiej. Heneczek wraz z ks. B. Purkopem wydali w tym celu 3000 ulotek z propozycją ustalenia katalogu książek. Po trzech miesiącach redakcja ,Zwiastuna..." otrzymała 251 odpowiedzi akceptujących współpracę w ośrodkiem wydawniczym w Niemieckich Piekarach, co

\footnotetext{
${ }^{35}$ Liczba abonentów w 1868 r. wynosiła zaledwie 330 osób, w okresie, gdy pismo redagował K. Miar$\mathrm{ka}-3300$, potem spadła do 1000 osób.

${ }^{36}$ Zob. ZG 1869, nr 2.

${ }^{37}$ Ślascy pisarze ludowi (1800-1914). Antologia poezji i prozy, oprac. J. Kucianka, Wrocław-Warszawa-Kraków 1968, pass.
} 
uznano za znaczący sukces ${ }^{38}$. Wśród współpracowników wspomnianego „Wydawnictwa..." należy wymienić: ks. Pawłowskiego z Osiecznej, który przesłał redakcji aż 11 swych manuskryptów, głównie tłumaczeń z języka niemieckiego i francuskiego, Jana Jankiewicza z Liska w Galicji, ks. Igancego Łobosa, radcę duchownego i kanclerza kosnystorza biskupiego w Przemyślu, i wielu innych. Nadesłane propozycje dotyczyły głównie literatury pobożnościowej i religijnej. W kwietniu 1869 r. „Zwiastun ...” powiadomił czytelników i współpracowników „Wydawnictwa Katolickiego Tanich a Dobrych Książek" o możliwości nabywania już kolejnych 33 tytułów druków piekarskich. W następnych latach T. Heneczek ${ }^{39}$ w kolejnym Uwiadomieniu zachęcał czytelników do zakupienia nowo wydanych książek. Reklamowane dzieła korespondowały $\mathrm{z}$ wydawnictwami piekarskiej serii na płaszczyźnie światopoglądowej, tj. propagowania wartości religijnych i społecznych. Propagowanie „Wydawnictwa Katolickiego...” oraz oparcie tego zamierzenia na szerokiej współpracy z duchownymi bez wątpienia przyczyniło się do zwiększenia liczby abonentów „Zwiastuna Górnośląskiego”.

Gdy w marcu 1869 r. pismo opuścił K. Miarka, „Zwiastun...”, mimo działań zmierzających do utrzymania poziomu pisma, stracil swój dotychczasowy charakter wychowujący, pouczający $i$ informacyjny. Pismo przybrało wyraźny „,charakter prusko-wiernopoddańczy”. Zmianę wymowy tego czasopisma dostrzeżono natychmiast nie tylko na Górnym Śląsku, ale i w Poznańskiem ${ }^{40}$ i Krakowskiem. Wielu czytelników zrezygnowało wtedy $z$ abonamentu czasopisma. Odtąd Heneczek realizował hasło: ,Z Bogiem za króla i ojczyznę" [niemiecką]. Siegnął zatem do historii, wyszukując $w$ niej budujących przykładów natury religijno-moralnej. Od 1870 r. przeciwnicy „Zwiastuna...” coraz częściej wysuwali pod adresem redakcji zarzut, że artykuły są skomplikowane, „dochodzą do dewocji”, a w zbyt małym stopniu przyczyniają się do politycznego uświadomienia społeczeństwa polskiego, które tego właśnie oczekuje.

Od połowy 1870 r. proboszcz piekarski i kustosz sanktuarium maryjnego ks. B. Purkop, zgodnie z poleceniem władz kościelnych we Wrocławiu, zaprzestał podpisywania „Zwiastuna Górnośląskiego” jako jego naczelny redaktor ${ }^{41}$, co oznaczało, że katolickie duchowieństwo śląskie oficjalnie wycofuje się z popierania zaślepionego nienawiścią do K. Miarki wydawcy Heneczka i jego czasopisma. Nie pomogły nawet kolejne Uwiadomienia drukowane w „Zwiastunie...”, w których Heneczek zachęcal do zakupienia nowo wydanych przez siebie książek. Były to: opowiadania historyczne Konrada Bolandena pt. Bóg żyje w przekładzie ks. N. Bonczyka, który został za to skazany przez władze pruskie na dwa miesiące więzienia, Nowy Bóg tegoż samego autora - T. Heneczek określił, że jest to opo-

\footnotetext{
${ }^{38}$ J. Saratowicz-Stolarzowiczowa, Teodor Heneczek..., dz. cyt., s. 20.

${ }^{39}$ Zob. np. ZG 1872, nr 6.

${ }^{40}$ Por: „Przyjaciel Ludu” [Leszno] 1869, nr 12.

${ }^{41} \mathrm{~K}$. Prus, O pierwszych polskich drukarzach $i$ wydawcach na Ślasku Górnym to $i$ owo, Mikołów
} 1920 , s. 23 n. 
wiadanie o tym, ,jak nowomodne państwo pragnie usunąć starego Boga i obalić królestwo Boże na Ziemi jednym słowem”, dążenia do usunięcia Papieża i błędne zasady wolnomularzy przedstawione w kolejnej powieści pt. Kielnia albo Krzyż. Wykorzystywanie czasopisma w sporach $\mathrm{z}$ utalentowanym K. Miarką mocno raziło jego czytelników. Proces rezygnacji czytelników ze „Zwiastuna...” przyspieszył niezgodny $z$ odczuciem społecznym polityczny ton tego tygodnika piekarskiego, którego wymowa w dalszym ciągu była bardzo lojalna względem władz pruskich. „Zwiastun...” przestał ukazywać się w końcu 1872 r. Odtąd Heneczek nie odgrywał większej roli w działalności religijno-społecznej Górnego Śląska. Nie można jednak zapomnieć, że w latach 1868-1872 corocznie ukazywały się 52 numery tego czasopisma (tj. 416 stron polskiego druku, z wyjątkiem 1869 r. - 53 numery i 436 stron druku), utwierdzające polskie słowo na Śląsku i moblizujące ludność w pierwszej fazie istnienia czasopisma- do obrony Kościoła katolickiego w życiu publicznym w okresie kulturkampfu za pomocą legalnych form działania.

\section{4. „DODATEK ZWIASTUNA"}

Od 7.01.1870 r. ukazywał się „Dodatek Zwiastuna”, który można było kupić oddzielnie, w cenie 5 srebrnych groszy za kwartał, albo razem z gazetą macierzystą za 14 srebrnych groszy. Do 27 numeru (7.07.1870 r.) redaktorem sześciostronicowego pisma był nieprzygotowany do tej funkcji ks. B. Burkop, proboszcz w Niemieckich Piekarach i Książęco Biskupi Komisarz, po nim tę funkcję objął sam T. Heneczek. Artykuły zawarte w „Dodatku...” dotyczyły: zagadnien politycznych, gospodarskich $\mathrm{i}$ handlowych, wychowania religijnego $\mathrm{z}$ uwzględnieniem bogatej hagiografii. „Doniesienia polityczne”, głównie z Prus, Galicji, Rosji i Rzymu, redagowane były jednak ciekawiej niż te, które zamieszczano w piśmie macierzystym. Osobny dział stanowiły „Rozmaitości” zawierające ciekawostki z różnych dziedzin i krajów świata. Spora część artykułów stanowiła streszczenie lub przedruk z czasopism: lwowskich, tarnowskich, poznańskich i krakowskich. Bardzo interesującą ich część stanowiła rzadko pojawiająca się korespondencja misjonarzy $\mathrm{z}$ różnych krajów. Wiele artykułów dotyczyło aktualnych spraw lokalnych, np.: sytuacji na wsi, walki z plagą alkoholizmu, przyczyn chorób, wychowania młodzieży. Na osobny dział składały się wiadomości adresowane do rolników i gospodarzy. Składały się na nie: Prognoza pogody, szczegółowe informacje o wschodach i zachodach Słońca, sposoby uprawy konkretnych jarzyn i warzyw, nowoczesny sposób karmienia bydła, uprawy roli, a także przysłowia. Stałą rubrykę stanowiły daty jarmarków: „I. W Prusach Wschodnich, II. W Prusach Zachodnich, III. W Wielkim Księstwie Poznańskim, IV. Na Szląsku, V. W Pomeranii i dalszych Niemczech, VI. Na Szląsku austriackim i VII. W Galicji i Wielkim Księstwie Krakowskim”. Często podawano także notowania rolniczej Giełdy Wrocławskiej. Prawie każdy egzemplarz „Dodatku Zwiastuna” zawierał krótki wiersz nadesłany przez któregoś z czytelników. Zazwyczaj sygnowano je inicjałami, rzadko kryptonimami. Czasem obok 
inicjałów autora podawano inicjał miejscowości, z której pochodził ludowy i niewykształcony twórcy wiersza. Redakcja „Dodatku Zwiastuna” prawie w każdym numerze zamieszczała reklamę jednej z nowowydanych w Poznaniu, Krakowie ${ }^{42}$, Opolu $^{43}$, Wrocławiu ${ }^{44}$, a nawet w Berlinie ${ }^{45}$ książek lub czasopism. Najczęściej były to: „Gwiazdka Cieszyńska”, lwowskie - „Przyjaciel Domowy”, „Dzwonek”, „Opiekun Polskich Dzieci”, „Rękodzielnik” i „Chata” oraz krakowski „Włościanin" "46. Bez wątpienia poszerzały one zakres świadomości czytelników, pogłębiając także ich wiedzę, nawet w dziedzinie osiągnięć technicznych. Dział Uwiadomienia również często gościł na łamach „Dodatku Zwiastuna”. Redakcja zamieszczała w nim reklamy różnych sklepów: tekstylnych, tzw. korzennych, kapeluszy, palarni kawy, Fabryki Asfaltu i Tektury dachowej braci Frey w Królewskiej Hucie ${ }^{47}$, składów naczyń i sprzętów kościelnych, reklamowała także handel winem, wymieniała „towary do bielenia” czy też „piękne, nowe dubeltówki (flinty)”48. Od 15. numeru „Dodatek Zwiastuna” wprowadził dział zagadek, które pisane były także przez niektórych duchownych, m.in. znanego działacza oświatowego i publicystę ks. A. Stabika cieszącego się nieustanną popularnością. Uznawano to za bardzo trafną decyzję redakcji, bowiem spora liczba czytelników zaangażowała się z ich rozwiązywanie. $\mathrm{W}$ tej grupie czytelniczej znalazły się także dzieci i młodzież, co pozwalało na wdrożenie nawyku czytania prasy polskiej. Jednak irracjonalny i prawie obsesyjny spór Henneczka z K. Miarką ${ }^{49}$ oraz jego „Katolikiem” spowodował znaczny spadek popularności redaktora „Dodatku Zwiastuna”, który de facto „nie miał ani wprawy, ani potrzebnego wykształcenia, ani wreszcie chęci do wyłącznego oddania się dziennikarstwu" 50 . Obecność na rynku prasowym „Dodatku Zwiastuna” zakończyła się wraz z 52. numerem macierzystego czasopisma z dnia 30.12.1870 r., wydawanego nakładem i pod redakcją T. Heneczka ${ }^{51}$. Chociaż Heneczek, zdaniem prasoznawców, polował na sensacje, które niezwykle ubarwiał i wykorzystywał aż do znudzenia do momentu pojawienia się nowych, „Dodatek...” przestal być atrakcyjny dla społeczeństwa, podobnie jak i jego macierzysta gazeta. Dla społeczeństwa opiniotwórcze stało się czasopismo „Katolik”, wydawane przez K. Miarkę od

${ }^{42}$ Np. Warownia Krzyża. Zob. „Dodatek Zwiastuna” 1870 [dalej: DZ] nr 26; Antychryst DZ 1870, nr 19.

${ }^{43}$ Święta Droga krzyżowa błog. Leonarda de Porto Maurizio, Ksiazka Modlitewna do najslodszych serc Zbawiciela i Matki jego Najświętszej, ks. J. Cytronowskiego Historią cudownego Obrazu Najświętszej Maryi Panny Piekarskiej w Kościele Opolskim, tudzież kilka uwag i modlitw skutecznych. Zob. DZ 1870, nr 9.

${ }^{44}$ Ustawa nowych miar $i$ wag z tabelami zmiany cen. Zob. DZ 1870 , nr 8.

${ }^{45}$ Zob. DZ nr 24. Rekomendowano w nim książkę pt. Przyjaciel Dzieci czyli Książka do czytania dla katolickich szkót elementarnych wydanq przez Ksaw. F. A. E. Lukaszewskiego, piąte wydanie poprawione przez Maksymiliana Kawrzyńskiego.

${ }^{46} \mathrm{DZ} 1870, \mathrm{nr} 12$

${ }^{47} \mathrm{DZ}$ nr 17.

${ }^{48} \mathrm{DZ}$ nr 14

${ }^{49}$ Zob. m.in. DZ 1870, nr 21.

${ }^{s_{0}}$ W. Ogrodziński, Dzieje piśmiennictwa ślqaskiego..., dz. cyt., s. 119.

¿1 Inną datę zaprzestania druku, mianowicie 1872 r., podają: M. Przywecka-Samecka, J. Reiter, Bibliografia polskich czasopism ślaskich (do 1939 roku), Wrocław 1960, s. 15 [na powielaczu]. 
kwietnia 1869 r. Odtąd to właśnie czasopismo zaczęło odgrywać wszechstronną rolę na rynku prasowym, stając się najbardziej znaczącym środkiem komunikacji społecznej w katolickim ruchu polskim i synonimem każdego polskiego czasopisma walczącego w obronie polskiej ludności Górnego Śląska.

\section{5. „PROMOTOR NABOŻEŃSTWA DO Ś.[W.] JÓZEFA I PRZENAJŚWIĘTSZEJ RODZINY"}

W czwartym kwartale $1870 \mathrm{r}$. Teodor Heneczek, w odpowiedzi na spadającą po odejściu K. Miarki liczbę prenumeratorów „Zwiastuna Górnośląskiego”, podjął się wydawania w Niemieckich Piekarach czasopisma ściśle religijnego, o charakterze formacyjnym, pt. „Promotor nabożeństwa do św. Józefa i Przenajświętszej Rodziny". Zdaniem niektórych prasoznawców, podtytul periodyku głosił, iż są to „Wiadomości miesięczne o nieustającym na Jego cześć nabożeństwie bractw i stowarzyszeń i o łaskach otrzymanych przez Jego przeważną przyczynę" ${ }^{2}$. Nie można jednak tego w pełni potwierdzić, ponieważ zachowane w Bibliotece Śląskiej w Katowicach roczniki II i III „Promotora...”, tj. poszyty z lat 1871 i 1872 , nie mają tego podtytułu ${ }^{53}$. „Promotor nabożeństwa do Ś.[w.] Józefa i Przenajświętszej Rodziny" ukazywał się nakładem Wydawnictwa Katolickiego, które w opinii jednego z najwybitniejszych etnografów i folklorystów górnośląskich S. Wallisa (1895$1957)^{54}$ znajdowało się ,pod nadzorem duchowieństwa, co było niejako dalszym ciągiem wydawnictw ks. Ficka" ${ }^{55}$. Zaradny i dbający o swój stan majątkowy T. Heneczek, licząc na poparcie duchowieństwa, nabył prawa wydawnicze do tego miesięcznika od członkiń wspólnoty kontemplacyjnej Zakonu Najświętszej Panny z Góry Karmelu - karmelitanek bosych z Poznania ${ }^{56}$. „Promotor...” ukazywał się początkowo co 5 tygodni, a wydawany był przez trzy kwartały 1870 r. w Poznaniu, w objętości 3-4 arkuszy, przez byłego nauczyciela, wydawcę i nakładcę T. Daszkiewicza $^{57}$, który w 1869 r. w Poznaniu, przy ul. Wodnej 28, założył księgarnię nakładową i sortymentową, głównie $\mathrm{z}$ inicjtywy wspomnianych zakonnic klauzuro-

s2 Polskie czasopisma religijno-spoleczne w XIX wieku. Materialy do katalogu, red. B. Lesisz, C. Drapinska, D. Olszewski, Warszawa-Lublin 1988, s. 533. Periodyk wydawany w Niemieckich Piekarach stanowił polską wersję „Promotora...”, ukazującego się we Francji pod redakcją ks. W. O. Hugueta.

${ }_{53}$ Zob. współoprawne roczniki „Promotora..." Biblioteka Śląska w Katowicach, sygn. II 350120/0/ 1871 SL oraz II 350120/0/1872 SL.

${ }^{54}$ J. Helik, Stanistaw Wallis (1895-1957), [w:] Świętochtowickie pamiqtki pióra, red. E. Brzozowski, S. Wajda, Świętochłowice 1994, s. 187-189.

${ }^{55}$ S. Wallis, Drukarstwo w Piekarach, [w:] Zbiory S. Wallisa. Muzeum w Chorzowie, mps., s. 6, sygn. MCH nr 1421. Ponadto „Komitet doradczy [Wydawnictw Katolickich], złożony z księży, miał badać rękopisy i zalecał wartościowe dzieła do druku, a niemniej czuwać nad ceną dzieł, aby była niska".

${ }_{56}$ Polska mutacja „Promotora nabożeństwa do Św. Jozefa...” byla thumaczona przez karmelitanki bose w Poznaniu pod kierownictwem ks. kanonika T. Mariańskiego.

${ }^{57}$ Zob. Z. Steidel, Daszkiewicz Tytus, [w:] Slownik pracowników ksiq̨żki polskiej, Warszawa.Lodź 1972 , s. 160. 
$w_{y y c h}^{58}$. Niemieckie Piekary jako miejscowość pielgrzymkowa wielokrotnie zwiększała chłonność rynknu wydawniczego. Heneczek już od września 1870 r. - licząc na zysk - rozpoczął druk tego periodyku w Niemieckich Piekarach. Zdawał sobie sprawę z tego, że „Promotor...” trafia tylko do relatywnie wąskiej elity katolików pogłębiających swą wiarę, dlatego obniżył cenę periodyku o połowę, mając nadzieję na skromy, jednak systematyczny zysk ${ }^{59}$. Orzeczenie soboru watykańskiego I, który właśnie w 1870 r. oddał ,św. Józefowi Kościół Święty w opiekę i ustanowił uroczyste święto $w$ dzień św. Józefa oraz polecił, aby szczególniejsze nabożeństwa do tegoż Patrona [były] pomnażane" ${ }^{60}$, zdaniem wspomnianego wydawcy, potwierdzało słuszną decyzję nie tylko jeśli chodzi o zakup tego tytułu prasowego, ale także w kwestii obniżenia jego ceny. Wzrost zainteresowania się postacią św. Józefa w Kościele powszechnym sugerował większy zbyt czasopisma i był niejako gwarancją uzyskiwania stałych dochodów. Ponadto aby zwiększyć pewność korzyści materialne, Heneczek przekształcił pismo w dwumiesięcznik ${ }^{61}$. Miało ono skromny wygląd modlitewnika o wymiarach $10,5 \mathrm{~cm}$ x $16,5 \mathrm{~cm}$. oczywiście pozbawionego jakichkolwiek ilustracji. Decyzje Heneczka sprawiły, że „Promotor nabożeństwa do św. Józefa...", obok innego pisma religijnego założonego przez K. Miarkę pt. „Monika. Tygodnik dla rodziców o chrześcijańskim wychowaniu dziatek” (1876-1878), które zawierało także sporo materiału beletrystycznego, docierając aż do 2 tys. prenumeratorów, stanowił jedną z podstawowych dróg pogłębionej ewangelizacji, prowadzonej przez rozwijające się i docenione już przez Kościół katolicki środki masowego przekazu w ostatnim trzydziestoleciu XIX w. ${ }^{62} \mathrm{Z}$ tego względu każdy rocznik „Promotora..." posiadał stosowne imprimatur, potwierdzone dokumentem znanego obrońcy niezależności Kościoła wobec władz pruskich w okresie kulturkampfu „Arcybiskupa [metropolity] Gnieźnieńskiego i Poznańskiego - Miecislausa" [Mieczysława Ledóchowskiego]. Ponadto Heneczek zaopatrywał każdy rocznik w spis treści z podziałem na część historyczną, uwzględniającą rozwój nabożeństwa do św. Józefa w Kościele katolickim w przestrzeni wieków oraz osobę św. Józefa w aspektach, ,jak go przedstawiają Święci Pańscy i mistrzowie życia wewnętrznego". Autorem tej części specyficznego perdiodyku-modlitwenika był jezuita O. Bouix. Ów zakonny mistrz życia wewnętrznego przywoływał świadectwa dotyczące Opiekuna Świętej Rodziny autorstwa takich świętych jak: Jan Chryzostom (ok. 349-407), biskup Poitiers Hilary (315-367 lub 368), biskup Hippony oraz doktor Kościoła Augustyn (354-430), Hieronim (345-419 lub 420), Piotr Da-

\footnotetext{
${ }^{58}$ Tamże.

${ }^{59}$ Zdaniem Heneczka, poznański drukarz z chęci zysku wyznaczył za czasopismo wygórowaną cenę - za 11 poszytów żądał 25 srebrnych groszy.

${ }^{60}$ Od 1691 r. w liturgii łacińskiej dzień 19.03. poświęcono św. Józefowi [święto obowiązujące]. W 1870 r. Pius IX uroczyście ogłosił św. Józefa patronem całego Kościoła, co wówczas - obok przesłanek religijnych - miało na Górnym Śląsku symboliczną, a nawet polityczną wymowę.

${ }^{61}$ ZG 1872, nr 52.

${ }^{62}$ "Monika" była pierwszym na ziemiach polskich pod zaborami czasopismem dla ludu koncentrującym się na tej tematyce.
} 
miani (1007-1072), „mąż ogromnej aktywności literackiej” Bernard z Clairvaux (1090-1153), Tomasz z Akwinu (1221-1274), autor wielu dzieł filozoficznych i teologicznych Bonawentura (1221-1274), założyciel zreformowanej gałęzi zakonu franciszkańskiego Bernardyn Sieneński (1330-1444), Gertruda Wielkiej z Helfty (1256-1302), założycielka Zakonu Najświętszego Zbawiciela Brygida Szwedzka (ok. 1302-1373), Teresa Magdalena de Pazzi ${ }^{63}$ czy biskup oraz doktor Kościoła Franciszek Salezy (1567-1622). Na pozostałą treść składały się m. in. rozprawki: Św. Józef wzór gorliwości o dusz zbawienie ${ }^{64}$, a także Wzór prawdziwego nabożeństwa do Najświętszej Maryi Panny ${ }^{65}$. Kolejne rozprawki pouczały, jak należy obchodzić uroczystość św. Józefa ${ }^{66}$, przypominały trzydniowe nabożeństwa do tego Świetego w kościele wspolnoty kontemplacyjnej w Poznaniu ${ }^{67}$. Wydzieloną część treści stanowiły łaski otrzymane za przyczyną św. Józefa, jak: ułatwienie wstąpienia do klasztoru, cudowne ocalenie budynku klasztornego, nawrócenie umierającej dziewczyny, wybawienie $\mathrm{z}$ kłopotu pewnej przełożonej domu zakonnego, nagłe uzdrowienie cierpiącej zakonnicy, ostatnie chwile pewnego zakonnika, wyraźny dowody opieki św. Józefa na morzu, uleczenie z przewlekłej choroby, ochrona przed chorobą epidemiczną i inne. Na ostatnich stronach poszytów zamieszczano ustawy Bractwa św. Józefa w Poznaniu, zachętę do nieustannej czci św. Józefa oraz sposoby odmawiania modlitw ku czci Opiekuna Najświętszej Rodziny. Przedstawiono także Nabożeństwa do Najdroższej Krwi Chrystusa ${ }^{68}$. Wydawca nie podawał w tych częściach modlitewnika autora tekstów. Można domniemywać, iż autorem Wiadomości o Bractwie św. Józefa w Poznaniu mógł być sam ks. kanonik T. Mariański.

Rocznik „Promotora...” wydawany przez Heneczka w Niemieckich Piekarach, składający się z 12 tzw. poszytów, kosztował 12 srebrnych groszy. Trudno jednak definitywnie stwierdzić, $z$ ilu stron składał się każdy poszyt $z$ lat 1871 i 1872, ponieważ po ich połączeniu i oprawie intrologatorskiej tworzył komplementarną, chociaż specyficzną książkę do nabożeństwa. Jakkolwiek pismo, drukowane w $1871 \mathrm{r}$. aż w 5 tys. poszytów ${ }^{69}$, odzwierciedlało zainteresowanie się Kościoła katolickiego oblubieńcem Najświętszej Maryi Panny, wskazywało na Jego królewskie pochodzenie $z$ rodu Dawida, podawało teologiczne podstawy przywilejów św. Józefa, omawiało Jego misję w Kościele, podkreślając, iż jest wzorem robotnika i małżonka, a także obrońcą przeciwko dechrystianizacji (laicyzacji i ateizacji) społeczeństwa, nie znalazło wielu odbiorców. Treść poszytów zapewne była mało atrakcyjna dla prostego czytelnika, często abstrakcyjna, a więc w niewielkim

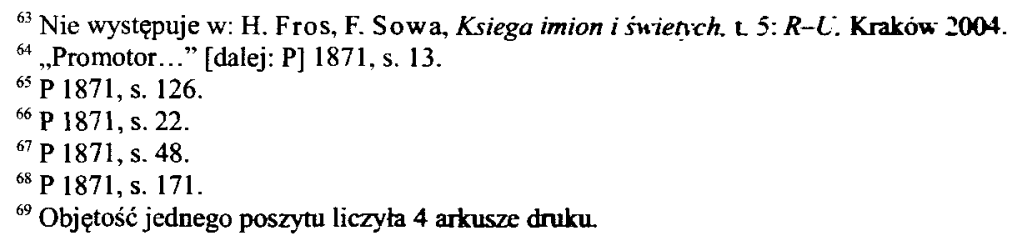


stopniu lub wręcz nie trafiająca do odbiorców. Pismo nie przynosiło zatem spodziewanych dochodów. T. Heneczek próbował jeszcze (jak się wydaje nie zawsze w sposób w pełni etyczny) znaleźć sponsora w osobie słynnego proboszcza bytomskiego ks. J. Szafranka, ale i ta próba zakończyła się niepowodzeniem ${ }^{70}$. Wszystkie te okoliczności zmusiły go do sprzedania drukarni mieszkańcowi miejscowości sanktuaryjnej - niejakiemu Kadukowi lub innej osobie mieszkającej w domu Kaduka w [Niemieckich] Piekarach przy głównej ulicy ${ }^{71}$. Ten $\mathrm{z}$ pewnością nie był tak obrotny w interesach, jak Heneczek. W miejscowości sanktuaryjnej nastąpił zatem kilkunastoletni zastój w ukazywaniu się polskich czasopism.

\section{6. „GWIAZDA PIEKARSKA. \\ PISMO LUDOWE, POŚWIECONE SPRAWOM POLITYCZNYM, SPOEECZNYM I OŚWIACIE"}

Dnia 16.06.1888 r. w drukarni Teofila Nowackiego w Niemieckich Piekarach ukazał się tzw. Prospekt, tj. druk ulotny o wymiarach $23,5 \mathrm{~cm} \mathrm{x} 40 \mathrm{~cm}$, zapowiadający, iż od 1.07. t.r. wydawany będzie tzw. półtygodnik „Pismo ludowe, poświęcone sprawom politycznym, społecznym i oświacie” pod tytułem „Gwiazda Piekarska". Podpisani pod Prospektem redaktor Franciszek Xawery Tuczyński, szewc Franciszek Schwider [Świder] oraz właściciel drukarni T. Nowacki reklamowali nowe czasopismo, które miało ukazywać się w środy i soboty, w objętości jednego arkusza drukarskiego. „Gwiazda Piekarska” miała „podawać wiadomości o wszelkich najnowszych zdarzeniach i wypadkach, wiadomości kościelne, polityczne, sejmowe, zajmujące historie, wiadomości prowincjalne, handlowe, literackie, rozmaitości, kursa pienieżne oraz ogłoszenia" ${ }^{\prime 72}$. Prospekt informował też, że numer okazowy czasopisma dużego formatu $(41 \mathrm{~cm}$ x $28 \mathrm{~cm})$, w nakładzie 10 tys. egzemplarzy, ukaże się 16. 06. t.r. ${ }^{73}$ Do prenumeraty czasopisma zachęcała jego niska cena - w Rzeszy Niemieckiej 1 marka kwartalnie, w Austrii zaś 75 centów. W miejscowości sanktuaryjnej koszt prenumeraty mieścił się w kwocie 85 fenigów lub ,odnoszeniem do domu, w 1 marce" ${ }^{74}$. W Prospekcie wydawcy czasopisma uzasadnili także nazwę gazety, nawiązującą do zainicjowanych w Niemieckich Piekarach przez ks. J. Ficka ekspresyjnych, masowych ruchów społecznych, które jak „pierwsze promienie światła duchowego poczęły padać na Górny Śląsk”" ${ }^{\text {. }}$. Pierw-

\footnotetext{
${ }^{70}$ ZG 1872, nr 52. W 1873 r. „Promotor nabożeństwa do Św. Józefa i Przenajświętszej Trójcy” ukazywał się w Gnieźnie.

${ }^{71}$ Ten zasłużoną drukarnię sprzedał Bornefeldowi z Bytomia. Potem drukarnia przeszła w ręce Kiela, wydawcy czasopisma o wyraźnym nastawieniu antypolskim - „Grenzzeitung”.

${ }_{72}$ Prospekt, N.[iemieckie] Piekary [druk ulotny].

${ }^{73}$ J. Wy cisło, Działalnośc wydawnicza i cywilizacyjna Stanislawa Kostki Czerniejewskiego w częstochowskiej „,Kartce Ogtoszeń...” i lokalnych czasopismach ślqskich, [w:] Stanisława Kostki Czerniejewskiego podania ludowe o Matce Bożej z Piekar na Ślqsku, Katowice 2001, s. 23.

${ }^{74}$ Prospekt.

${ }^{-\xi}$ Tamże.
} 
szy numer pisma pojawił się na rynku $1.07 .1888 \mathrm{r}$. Liczył cztery strony. Każda strona podzielona była na trzy szpalty. Druk był wyraźny, tłoczony dużymi i zróżnicowanymi czcionkami ${ }^{76}$. Redaktor odpowiedzialny początkowych 28 numerów pisma F. Tuczyński szybko wycofał się z osobliwej spółki. Redakcję „Gwiazdy...” przejął więc S. Czerniejewski, reprezentujący poglądy ultramontańskie i nadmiernie wynoszący autorytet duchownych. Czasopismo pełne było informacji kościelnych; sprawami politycznymi $-\mathrm{z}$ obawy przed grożącymi procesami $-\mathrm{S}$. Czerniejewski się nie zajmowal ${ }^{77}$. Dokonywał jedynie przedruków tego rodzaju wiadomości $\mathrm{z}$ innych gazet ${ }^{78}$. Gdy kolejny członek spółki F. Świder przekonał się, że wydawanie „Gwiazdy Piekarskiej” nie gwarantuje większych zysków, również się z niej wycofał. Odtąd S. Czerniejewski musiał sam podołać wszystkim obowiązkom drukarskim, redakcyjnym i kolporterskim. Ponieważ nie miał odpowiednich funduszy, korzystał z kapitału krewnych swej żony z Łysakowskich. Zapewniał czytelników, iż będzie „ogrzewać i zachęcać do dobrych czynów w miłości i pokoju” ${ }^{\text {, }}$, przytaczać „przykłady, jak narody, które kochają się wzajemnie, są szczęśliwe i giną tylko te, co noszą w sercu nienawiść" ${ }^{80}$. Permanentny brak kapitału redakcyjnego musiał ujemnie wpływać na profil ideowy czasopisma, które nie miało stałych współpracowników. Wyjątek stanowił aktywny działacz społeczny w środowisku robotniczym Urban Działłach z Kozłowej Góry ${ }^{81}$ oraz Karol G. ${ }^{82}$ i J. N. z pobliskiego Radzionkowa ${ }^{83}$. $Z$ tego też powodu zasięg czasopisma $\mathrm{z}$ pewnością był ograniczony.

Dnia 9.04.1892 r. „Gwiazda Piekarska” stała się organem wydawniczym Związku Górnośląskich Robotników Wzajemnej Pomocy, co wskazywało, iż zamierza głębiej reagować na wydarzenia dotyczące polskiego społeczeństwa i ludzi ciężkiej pracy. Warto pamiętać, że w tym samym roku przeprowadzono też wielką akcję na rzecz używania języka polskiego w szkole. Wzorowo zorganizowali ją łącznie duchowieństwo i osoby świeckie. Pod petycją w tej sprawie do rządu pruskiego lud śląski złożył 126 tys. podpisów. Petycję podpisali mieszkańcy $90 \%$ miejscowości powiatu tarnogórskiego, w skład którego wchodziły też [Niemieckie] Piekary $^{84}$. Redakcja „Gwiazdy Piekarskiej” oczywiście popierała postulaty polskiego społeczeństwa.

\footnotetext{
${ }^{76}$ Pojawienie się nowego czasopisma społeczeństwo przyjęło entuzjastycznie, o czym świadczy m.in. wiersz L. Fuchsa. Zob. „Gwiazda Piekarska” 1888, nr 45.

${ }^{77}$ Mimo to władze pruskie były w tym okresie wyraźnie zdezorientowane rozwojem i linią polityczną czasopism polskich na Górnym Śląsku, „w równym stopniu interesując się „Katolikiem”, jak i periodykami o mniejszym znaczeniu”, m.in. „Gwiazdą Piekarską”. Zob.: J. Glensk, Pitaval prasy polskiej na Ślasku w XIX stuleciu. Redaktorzy $i$ wydawcy przed sadem, Opole 1992, s. 245, przyp. 6.

${ }^{78}$ M. Pater, Ruch polski na Gómym Śląsku w latach 1879-1893. Wrockaw 1968, s. 175 n.

${ }^{79}$ „Gwiazda Piekarska” [dalej: GP] 1888, nr 28.

${ }^{80}$ Tamże.

${ }^{81}$ Zob. GP 1888, nr $41-42$.

${ }^{82}$ Tamże, nr 36.

${ }^{83}$ Tamże, nr 38.

${ }^{84}$ A. Targ, Życie polskie w powiecie $w$ drugiej polowie XIX wieku i w poczqtkach XX wieku, [w:] Tarnowskie Góry. Zarys rozwoju miasta, red. H. Rechowicz, Katowice 1969, s. 164 n.
} 
Więcej artykułów o charakterze politycznym S. Czerniejewski zaczął zamieszczać w „Gwieździe...” w 1893 r., z racji wyborów do parlamentu niemieckiego. W wyborach tych $\mathrm{z}$ ramienia partii Centrum stawał wówczas bardzo lubiany proboszcz piekarski ks. Leopold Nerlich (1886-1895). Jednak społeczność polska po raz pierwszy w procesie odrodzenia politycznego na Śląsku zaczęła odróżniać funkcję księży jako duchownych od ich zaangażowania politycznego. Chociaż S. Czerniejewski na łamach „Gwiazdy Piekarskiej” opowiadał się za miejscowym proboszczem, Polacy nie poparli znanego duchownego, lecz jego kontrkandydata majora J. Szmulę ${ }^{85}$.

S. Czerniejewski publikował w „Gwieździe...” różne gatunki literackie, wśród których dominowały: powiastka, opowiadanie, powieść w odcinkach, a niekiedy krótkie formy liryczne, mimo to czasopismo zawsze zmagało się z trudnościami finansowymi, a liczba jego abonentów nie przekroczyła tysiąca osób ${ }^{86}$. Nie pomogły trzykrotna zmiana winiety, radykalna obniżka ceny jednego egzemplarza, apele prasowe, odwoływanie się do ambicji i aspiracji kulturowych czytelników oraz ułatwienia w prenumeracie. Nawet ,zapisanie «Gwiazdy Piekarskiej» tylko na próbę" ${ }^{97}$ nie przyniosło spodziewanych efektów.

Program „Gwiazdy Piekarskiej” S. Czerniejewski kontynuował do końca swego pobytu w Niemieckich Piekarach - tzn. do 1.10 .1900 r., koncentrując uwagę na obronie języka polskiego, czasem podkreślając polski charakter społeczeństwa na Górnym Sląsku, jego historyczny, kulturalny oraz etniczny związek z resztą narodu $^{88}$. Już tylko $\mathrm{z}$ tego powodu warto podjąć głębszą analizę treści tego czasopisma. Zapewne pozwoli to bardziej docenić samotne wysiłki S. K. Czerniejewskiego w zakresie pogłębiania polskiej świadomości mieszkańców tego uprzemysłowionego regionu, poddanych przez kilka stuleci działaniom germanizacyjnym.

\section{7. „PRZY JACIEL DOMOWY. \\ PISMO POŚWIECCONE OŚWIACIE, UMORALNIENIU \\ I ROZRYWCE UMYSŁOWEJ"}

„Gwiazda Piekarska” od początku, tj. od lipca 1888 r., miała oryginalny, bezpłatny dodatek dwutygodniowy, zatytułowany „Przyjaciel domowy. Pismo poświęcone oświacie, umoralnieniu i rozrywce umysłowej". Pismo drukowano w Niemieckich Piekarach, w formacie $21 \mathrm{~cm}$ x $29 \mathrm{~cm}$. Każda z czterech stron dodatku

\footnotetext{
${ }^{85}$ On też zwyciężył w wyborach, otrzymawszy aż 21887 głosów, gdy tymczasem ks. L. Nerlich uzyskał tylko 10120 głosów.

${ }^{86}$ Sytuacji nie zmieniło nawet obniżenie w listopadzie i grudniu $1888 \mathrm{r}$. ceny egzemplarza 0 1/4 dotychczasowej wartości.

${ }^{87} \mathrm{GP} 1888, \mathrm{nr} 37$.

${ }^{88}$ J. Ratajewski (Obraz polskiej prasy na Górnym i Dolnym Ślasku w drugiej polowie XIX wieku. W: Studia nad piśmiennictwem ślaskim. Katowice 1988, s. 42 i 54 ) podaje, iż od 1. 07.1894 r. ukazywało się wydawane i redagowane przez J. Kokornczyka, drukowane przez „Gwiazdę...” w Piekarach, czasopismo „Skarbnik. Pismo humorystyczne dla Ludu Górnośląskiego”.
} 
składała się z dwóch szpalt. Drukowano je bardzo zróżnicowaną czcionką, co sprawiało, że z przyjemnością brało się je do rąk. Gdy 1.07.1888 r. „Przyjaciel Domowy" po raz pierwszy pojawił się na rynku wydawniczym, był jednym z pięciu dodatków do czasopism, jakie wówczas ukazywały się na Śląsku ${ }^{89}$. Reklamowany był jako pismo ilustrowane, chociaż archiwalna kwerenda zachowanych egzemplarzy nie może tego potwierdzić. Nie wiadomo, czy wychodził regularnie. $Z$ zachowanych egzemplarzy wiemy, że redakcji, a szczególnie S. K. Czerniejewskiemu pochodzącemu z Poznania, odpowiedzialnemu za pismo, bardzo zależało na tym, aby regularnie trafiał do rąk czytelników. Dodatek „Gwiazdy Piekarskiej” początkowo ukazywał się nakładem szewca Franciszka Świdra [Schwidra] i redaktora Czerniejewskiego. Drukowany był czcionkami pisma macierzystego w oficynie wydawniczej T. Nowackiego w N.[iemieckich] Piekarach. Kiedy między wspólnikami, tj. F. Swidrem i S.K. Czerniejewskim, doszło do rozbieżności zapatrywań na temat profilu programowego gazety macierzystej, a ponadto F. Świder zdał sobie sprawę $\mathrm{z}$ tego, że czasopismo i jego dodatek nie przynoszą zysku, w kwietniu $1890 \mathrm{r}$. wycofał się ze spółki. Odtąd Czerniejewski, pełniąc funkcję redaktora odpowiedzialnego ${ }^{90}$, wydawał „Przyjaciela Domowego" własnym nakładem. Dodatek „Gwiazdy Piekarskiej" razem z czasopismem macierzystym drukowany był w Bytomiu, przy ul. Gliwickiej 15. Ostatni numer „Przyjaciela Domowego...” ukazał się na początku października $1900 \mathrm{r}^{91}$, kiedy to S. Czerniejewski zrezygnował z wydawania „Gwiazdy Piekarskiej"92.

$\mathrm{Na}$ treść dodatku składały się krótkie artykuły światopoglądowe, do których należały m.in. Czyń dobrze, a resztę zdaj na Boga ${ }^{93}$, w kolejnym roku Narzędzia męki Jezusa Chrystusa ${ }^{94}$, Dziennik podróży Ojca świetego Piusa VI-go papieża do Wiednia w r. 1782 r. odprawionej ${ }^{95}$, opowieśc M.M ,według starych ksiąg” pt. Nasi praojcowie. Gdzie mieszkali, co robili, ich zwyczaje, obyczaje, religia, jak krajem rzadzili przed przyjeciem Chrześcijaństwa ${ }^{96}$ oraz długi szereg nauk pt. Skarb chrześcijanina ${ }^{97}$.

Osobny dział czasopisma stanowiły: ciekawostki, aforyzmy, szarady, zagadki, fraszki i humor. Niektóre z nich nadsyłali czytelnicy, co prowadziło do zacieśnienia

${ }^{89}$ J. Ratajewski, O dodatkach do czasopism ślaskich od końca XIX wieku do roku 1939. Szkic informacyjny. „Zaranie Śląskie” 1965, nr 4, s. 882.

90 "Przyjaciel Domowy” [ dalej: PD] 1890, nr 6 z dn. 4.04.

${ }^{91}$ Kwerenda prasoznawcza potwierdziła istnienie dodatku "Przyjaciel Domowy" do 11.09.1898 r. Zatem informacje zawarte w opracowaniu: M. Przywecka-Samecka, J. Reiter, Bibliografia polskich czasopism..., s. 117, jakoby dodatek zaprzestano drukować już w 1891 r. są mylne.

${ }_{92}$ J. Wycisło, Dzialalność Stanisława Kostki Czerniejewskiego - redaktora, wydawcy $i$ pisarza w Niemieckich Piekarach, [w:] W klimacie sląskiej humanistyki, red. J. Kwiatek, E. Sapia-Drewniak, Opole 2000 [?], s. 416.

${ }^{93} \mathrm{PD} 1889, \mathrm{nr} 5, \mathrm{z}$ dn. 16.01 .

${ }^{94} \mathrm{PD} 1890$, od $\mathrm{nr} 4 \mathrm{z}$ dn. 11.03 .

${ }^{95}$ PD 1890, od nr $11 \mathrm{z}$ dn. 17.06 .

${ }^{96}$ PD 1890 , od nr $17 \mathrm{z}$ dn. 19.09 .

${ }^{97}$ PD 1889, nr 14, z dn. 16.02. PD 1890, nr 9 z dn. 31.01. 
więzi między nakładcą i równocześnie redaktorem a kręgiem czytelniczym. Dział ten w urozmaicony sposób ożywiał „Dodatek do «Gwiazdy Piekarskiej»”, który ciekawił ludzi ciężkiej pracy zatrudnionych w pobliskich zakładach przemysłowych i w tzw. obszarze dworskim. Czerniejewski często zamieszczał w tej kolumnie wiersze m.in. Wincentego Pola, Juliusza Ligonia ${ }^{98}$, Emilii Lejowej, oraz utwory własne. Wiele publikowanych utworów nie było sygnowanych.

Istotne szpalty dodatku zawierały pobożne opowiadania $\mathrm{z}$ wątkiem sensacyjnym. Czerniejewski zaczął je publikować głównie od 7.04.1893 r., tj. wtedy, gdy po rocznej zawieszeniu druku „Przyjaciel Domowy...” zaczął ponownie docierać do czytelników, lecz w znacznie mniejszym formacie $-18 \mathrm{~cm}$ x $24 \mathrm{~cm}$. Prawdopodobnie redaktor postąpił $w$ ten sposób ze względów oszczędnościowych oraz $\mathrm{z}$ powodów osobistych. Wtedy też „Przyjaciel Domowy...” z pisma pouczającego i zarazem rozrywkowego stał się czasopismem zdominowanym przez tematykę religijno-moralną oraz historyczną. Każdy artykuł wstępny stanowił komentarz do perykopy ewangelicznej $\mathrm{z}$ danej niedzieli. Oprócz tego kolejny utwór pisany prozą lub rymem charakteryzował się także treścią religijną. Na pozostałą część czasopisma składały się sensacyjne lub historyczne opowiadania, rzadziej rozmaitości i fraszki, z czasem zastapione humorystycznymi wierszami anonimowego twórcy. Do jednych z ciekawszych opowiadań o wątku sensacyjnym należą: Zielony pugilares. Zdarzenie prawdziwe ${ }^{99}$, Janusz $w$ niewoli tatarskiej, Czarownica z Monterej ${ }^{100}$, Straszne więzienie czyli dawni Rycerze $e^{101}$, a potem powieść z $1740 \mathrm{r}$. W. Wójcickiego pt. Dobosz. Wreszcie Czerniejewski zaczął publikować dhugi cykl historyczny pt. Dzieje Polski, w którym przedstawił m.in. Obrone Trembowli ${ }^{102}$ i cykl opowiadań pt. Spiacy Biaty Orzel opisujący dumną historię Polski na podstawie dziejów miast: Gniezna, Krakowa, Poznania, Warszawy, oraz życia górali karpackich.

W 1895 r. Czerniejewski (prawdopodobnie na początku II półrocza) po raz kolejny zmienił format dodatku na bardziej okazały $(21 \mathrm{~cm} \mathrm{x} 31 \mathrm{~cm})$. Ozdobna winieta zawierająca piękny rysunek dworku szlacheckiego miała skłonić czytelnika do poważnego traktowania czasopisma. Ważna była - jak się wydaje - drobna zmiana tytułu z „Przyjaciela Domowego” na „Domowego Przyjaciela”. Czerniejewski zapełniał szpalty fragmentami powieści angielskiej pt. Biala lilijka, następnie urywkami Ubogiej wdowy Malgorzaty i jej syna Antosia. Ostatnia strona dodatku w całości przeznaczona została na „rozmaitości i fraszki”. W 1898 r. na łamach dodatku dominowały - naturalnie po części z komentarzem aktualnych na konkretną niedzielę perykop Ewangelii - opowieści umoralniająco-sensacyjne: Powrót emigranta, Szlifierz. Obrazek z bruku warszawskiego, oraz nowela Stanislawa Mił-

\footnotetext{
${ }^{98} \mathrm{PD} 1893, \mathrm{nr} 26 \mathrm{z}$ dn. 1.10.

${ }^{99}$ PD 1893, nr $1 \mathrm{z}$ dn. 7.04.

${ }^{100} \mathrm{PD} 1894$, nr $1 \mathrm{z}$ dn. 1.01 .

161 Tę powiastkę zaczęto drukować od II półrocza $1894 \mathrm{r}$.

Od PD 1893, nr $14 \mathrm{z}$ dn. 7.07 do PD 1893, nr $25 \mathrm{z}$ dn. 24.09.
} 
kowskiego pt. Żyd. Wcześniej na łamach dodatku drukowano opowiadanie Indianie na bezludnej wyspie z okolic Meksyko. Można domniemywać, że wszystkie opublikowane powiastki, fragmenty powieści i nowele wpływały na lekturę i poczytność dodatku „Gwiazdy Piekarskiej”.

Do innego rodzaju pobożnych opowiadań należały bez wątpienia drukowane w dodatku Wspomnienia o ks. kanoniku Ficku, b. [ytym] proboszczu przy kościele w Piekarach ${ }^{103}$. Nie mogło być inaczej, chociaż od chwili śmierci tego świątobliwego kapłana (18.02. 1862 r.) minęło już ponad ćwierć wieku. Społeczeństwo Górnego Śląska, i nie tylko, żyło na co dzień myślą o tym wspaniałym kapłanie i inicjatorze czterech spektakularnych, masowych akcji mających na celu odrodzenie religijno-moralne społeczeństwa poddawanego gwałtownym procesom industrializacyjnym $^{104}$. Postać zmarłego kapłana często przypominano w katolickiej prasie polskiej i niemieckiej (wrocławski „Schlesisches Kirchenblatt”, piekarski „Zwiastun Górnośląski”, bytomskie „Światło” i inne). Wydaje się zatem, że to czasopismo było bliskie „zwykłym” czytelnikom, popularnym na miarę ówczesnych możliwości redakcyjnych i okoliczności.

\section{8. „MIESIĘCZNIK ŻARTOBLIWY. PISMO DLA ŚMIECHU I ZABAWY".}

W lipcu 1888 r. redaktor „Gwiazdy Piekarskiej” Franciszek Xawery Tuczyński z Niemieckich Piekar wydał czcionkami drukarni „Katolika” w Bytomiu-Rozbarku pierwszy egzemplarz „Miesięcznika Żartobliwego. Pisma dla śmiechu i zabawy". Numer ten liczył 16 stron w małej ósemce $(12 \mathrm{~cm}$ x $18 \mathrm{~cm})$. Na czwartej stronie jasnoczerwonej okładki wspomniany redaktor i wydawca napisał: „Miesięcznik Żartobliwy wychodzić będzie co 1-go każdego miesiąca po cenie 20 fenigów. Zamówienia należy nadsyłać pod adresem: Fr. Xaw. Tuczyński w Królewskiej Hucie (Koenigshiitte) O.-S. Od 1-go lipca zamawiać można na pocztach po cenie 60 fen. kwartalnie. Do tego czasu nabywać można tylko w Ekspedycji w Królewskiej Hucie lub u pp. agentów. Należytności drobne najlepiej przesyłać w znaczkach pocztowych.

Celem «Miesięcznika» jest pobudzać Czytelników do wesołości i bawić ich niewinnemi zabawnemi powiastkami, jako i żartami. Cena każdego zeszytu jest tak tania, że zaiste za tę drobnostkę więcej będzie miał nabywając wesołości, aniżeliby jej za drogie pieniądze szukał gdzie indziej. Jest czas do tańca, jest i do różańca, mówi przysłowie, a Pismo św. Mówi: «Cieszcie się, ale nie grzeszcie». Otóż «Miesięcznik» będzie się starał, aby doborem niewinnych, a wesołych, żartobliwych ar-

${ }^{103}$ PD $1889 \mathrm{nr} 1, \mathrm{z}$ dn. 2.01 do PD $1889, \mathrm{nr} 9 \mathrm{z}$ dn. 1.05.

${ }^{104} \mathrm{Z}$ analizy treści przytoczonych Wspomnien... wynika, że był to przedruk popularnej pracy ks. K. Press freunda, byłego współpracownika w parafii sanktuaryjnej, pt. Życiorys ś.p. księdza Jana Alojzego Fiecka, Kanonika Honorowego, Officyala Biskupiego, Dziekana i Proboszcza Piekarskiego tudzież Kawalera Orderu Orla Czerwonego, Niemieckie Piekary 1873. 
tykułów dostarczył swym czytelnikom takiej uciechy. Niechże też i Szanowna Publiczność zechce takim drobnym wydatkiem poprzeć takie przedsiebiorstwo"105.

„Miesięcznik" otwierał wiersz pt. O potrzebie śmiechu. W dalszej kolejności wydawca umieścił powiastkę O Dziadzie - Śmiechoradzie i o królewnie, która śmiać się nauczyla, następnie zaś opublikowano krótki artukuł na temat śmiechu jako lekarstwa i zamieszczono wiersze pt. Gawęda o gorzatce, Sposób aby się wnet wzbogacić, anegdotę O Angliku, Szkocie i Irlandczyku i Przygodę w podróży. Numer zamykały trzy fraszki oraz trzy zagadki, a także piętnaście dowcipnych zapytań. Za „najlepsze" rozwiązanie zagadek można było otrzymac nagrodę, którą była napisana przez samego redaktora powieść historyczna pt. Mazepa, hetman Ukrainy ${ }^{106}$.

Redaktor odpowiedzialny zapewniał też, że: „ktoby chciał popróbować swego humoru w «Miesięczniku», ma do tego sposobność. Będą się także umieszczały humorystyczne, wesołe korespondencje, ale tylko takie, które czytelnika będą zdolne do śmiechu pobudzić".

Pracujący w oficynie wydawniczej Teofila Nowackiego w Niemieckich Piekarach redaktor F. Tuczyński, opublikował w numerze 11 „Gwiazdy Piekarskiej” $\mathrm{z}$ dnia 4.08.1888 r. wiadomość, że na rynku wydawniczym ukazał się kolejny, tj. drugi zeszyt, „Miesięcznika Żartobliwego”. Wydawnictwo zapewniało doręczenie przesyłki $z$ tym zeszytem pod wskazany adres za opłatą 3 fenigów w znaczkach pocztowych.

Nowy numer pisma zawierał Kazanie księżnej Glupskiej na Glupczycach, miane do swoich poddanych roku Pańskiego 2000 przed stworzeniem Adama, ponad 20 dowcipów, Mowę pani Doświadczyńskiej o mężach, bajkę wierszowaną o Dwóch przyjacielach i niedźwiedziu a także „historię ruską, po wiek wieki sławną, w starych ksiegach opisaną, za istną prawdę udaną" pt. Jako Bartek swego opętanego pana od czarta uwolnil. Egzemplarz zamykało 15 odpowiedzi na dowcipne zapytania z poprzedniego miesiąca.

Z analizy treści stopki „Gwiazdy Piekarskiej” z 10.11.1888 r. wynika, że F. X. Fuczyński wycofał się ze spółki i przestał był współnakładcą. W ten sposób wydawca i redaktor F. Schwider (Świder) przejął „Miesięcznik...”, który odtąd drukowany był czcionkami „Gwiazdy Piekarskiej” w Niemieckich Piekarach. Zmieniono wtedy tytuł periodyku na „Miesięcznik dla śmiechu i zabawy” i zaczęto zamieszczać dłuższe opowiadania, często w dwóch lub większej liczbie odcinków publikowanych w kolejnych numerach. Tak było np. w przypadku opowiadania pt. Dziad Chleburad i jego przygody ${ }^{107}$ i noweli Jako Janko niechcacy morskim rozbójnikiem zostal. Pismo radykalnie ograniczyło liczbę fraszek do pięciu, prezentowało tylko jedną wierszowaną zagadkę i podawało nazwiska kilku zwycięzców. Nie może zatem dziwić, że dwa pierwsze numery wydane przez F. Świdra nie cieszyły się po-

\footnotetext{
${ }^{105}$ „Miesięcznik Żartobliwy. Pismo dla śmiechu i zabawy” [dalej: MŻ], 1888, nr 1.

106 Tamże.

${ }^{10^{-}}$MŻ 1889 nr 5 i 6.
} 
pularnością ${ }^{108}$. Nie sprzedane egzemplarze zalegały magazyny. $Z$ tego też powodu wydawca nie mógł pokrywać kosztów związanych z edycją czasopisma. W numerze 6. „Miesięcznika...” z 1889 r. poprosił więc stałych czytelników, by zechcieli zachęcić innych do kupna kolejnego egzemplarza pisma. Obiecywał, że za „zwiększony zastęp Czytelników «Miesięcznika» wynagrodzi” wszystkim „doborem uciesznych i zabawnych artykułów”. Zgodnie z zapowiedzią w numerze „rozpaczy" opublikował m.in. humorskę Strachy i milość, w której trudno znaleźć cokolwiek z żartu i zabawy oraz zakończenie ,ciągnącego się" opowiadania pt. Jak Janek niechcacy morskim rozbójnikiem zostal. Na wyklejce czwartej strony okładki zamieścił tylko jedną fraszkę, a cały poszyt zamknął jedną zagadką. Zapewne ani apel wydawcy, ani tym bardziej treść poszytu nie zyskały aprobaty czytelników, gdyż F. Schwider zniechęcony brakiem dochodów odsprzedał pismo S. K. Czerniejewskiemu. Ten pochodzący z Poznania zapobiegliwy drukarz, pilny redaktor i wydawca opublikował 15.12. 1889 r. kolejny numer pisma humorystycznego, po raz kolejny zmieniając jego tytuł na „Miesięcznik. Pismo dla śmiechu i zabawy”. Cena periodyku nadal wynosiła 15 fenigów $^{109}$. Dalsze losy miesięcznika nie są jednak znane. Wydaje się, że redaktorzy przecenili swoje siły i inwencję tworczą, uważając, że samymi tylko długimi humoreskami, i to nie najwyższego lotu, zadowolą czytelników. Początkowy rozmach wydawcy i redaktora widoczny w pierwszym i drugim egzemplarzu „Miesięcznika” z 1888 r. szybko się rozwiał. Mimo wysiłków S. K. Czerniejewskiego, który znany był z sumiennego wywiązywania się $\mathrm{z}$ każdych podjętych obowiązków, pismo ciągle traciło czytelników. Nie pomogła nawet okresowa obniżka ceny egzemplarza do 10 fenigów. Wiadomo, że i ta dumpingowa cena oraz pozycja wydawnicza nie zdołała „uratować" S. Czerniejewskiego od dotkliwej porażki finansowej ${ }^{110}$. Po upadku ,jego" czasopism nastąpił prawie 25-letni zastój w rozwoju wydawnictw prasowych w miejscowości pielgrzymkowej.

\section{9. ,GŁOS Z NAD BRYNICY.}

\section{TYGODNIK POŚWIECONY SPRAWOM OŚWIATOWYM I SPOLECZNYM"}

W odmienionej sytuacji polityczno - narodowej na Górnym Śląsku, bo w stabilizującej się powoli II Rzeczypospolitej, na pół roku przed promulgowaniem przez papieża Piusa XI bulli Vixdum Poloniae unitas ${ }^{111}$, powołujacej biskupstwo katowickie podporządkowane metropolii w Krakowie (uniezależniające tym samym tę cześć Kościoła katolickiego w Polsce od niemieckiego biskupstwa we

${ }^{108}$ GP 1889, nr 49.

${ }^{109}$ S. Wallis, Piśmiennictwo polskie, [w:] Powiat świętochlowicki. Monografia, oprac. Komitet Redakcyjny pod przew. T. Szalińskiego, Katowice 1931, s. 338 n.; B. Groeschel, Die Presse Oberschlesiens von den Anfaengen bis zum Jahre 1945. Dokumentation und Strukturbeschreibung, Berlin 1993, s. 68.

${ }^{110}$ Prasa polska w latach 1864-1918, red. J. Lojek, Warszawa 1976, s. 213.

${ }^{111}$ Dnia 28.10.1925 r. W skład diecezji katowickiej weszły: Administracja Apostolska Polskiego Śląska oraz Wikariat Generalny Śląska Cieszyńskiego. 
Wrocławiu), dnia 11.04.1925 r. wydany został pierwszy numer nowego czasopisma górnośląskiego pt. „Głos z nad Brynicy. Tygodnik poświęcony sprawom oświatowym i społecznym". W winiecie tytułowej zaznaczono, iż ,zawiera ogłoszenia urzędów okręgowych, gminnych i parafialnych z Szarleja ${ }^{112}$, Wielkich Piekar, Brzezin, Brzozowic, Kamienia, Wielkiej Dąbrówki i okolicy”. Był to sześciostronicowy (lub ośmiostronicowy), dużego formatu $(44 \mathrm{~cm} \times 31 \mathrm{~cm})$, quasi-urzędowy organ wydawniczy kilku sąsiadujących $\mathrm{z}$ sobą gmin politycznych i parafii $\mathrm{z}$ rozbudowanym działem ogólnoinformacyjnym.

Redakcja i administracja nowego czasopisma mieściła się najpierw w [Piekarach] Szarleju, przy ul. Kamieńskiej 52, potem przy ul. Górnej 2, by znów znaleźć się w Szarleju przy ul. Kamieńskiej 52 oraz przy ul. Piekarskiej 22, w mieszkaniu Józefa Kołdonka, znanego działacza społeczno-oświatowego i kulturalnego. Ekspozycja znalazła miejsce w [Piekarach] Szarleju, w lokalu mieszkalnym i sklepie Pieczki, przy ul. Kamieńskiej 22. Początkowo czasopismo ukazywało się co sobotę. Miesięczna prenumerata $\mathrm{z}$ dostarczeniem do domu kosztowała 50 groszy, a pojedynczy egzemplarz - 15 groszy ${ }^{113}$. Kolporterami byli: w Szarleju Ścigała, ul. Dworcowa 22, sklep P. Pieczki, ul. Kamieńska 22, Ignacowa w księgarni ludowej przy targowisku; w Piekarach F. Gracka, ul. Gówna, Głazowski, ul. Kalwaryjska, w Brzozowicach - Kostosz, podobnie w Kamieniu, w Brzezinach - Bochynek, w Wielkiej Dąbrówce - Józef Lubojański, w Radzionkowie - Franciszek Gajda, ul. Damrota 68, w Bobrownikach - Przybyłek z Szarleja. Ogłoszenia przyjmował także Walter Mistol z Szarleja ${ }^{114}$. Za milimetrowy wiersz ogłoszenia pobierano 10 groszy ${ }^{115}$. Redaktorem odpowiedzialnym czasopisma był Jan Ludyga z [Piekar] Szarleja, tygodnik zaś drukowany był w „Katoliku”. „Sp. wyd. z ogr. odp. w Bytomiu" ${ }^{116}$, tj. w niemieckiej części Górnego Śląska. Czasopismo przez miesiąc ukazywało się nakładem Towarzystwa Przemysłowców w Szarleju, po czym przejęte zostało przez zespół pod nazwą „Wydział złączonych towarzystw w Szarleju” pod kierownictwem J. Kołdonka ${ }^{117}$. W skład zespołu redakcyjnego, oprócz J. Kołdonka i J. Ludygi, wchodzili: naczelnik Okręgu Urzędowego w Szarleju Wiktor Polak, redaktor działu rozrywkowego Teduś z rozciepu godo ${ }^{118}$, nauczyciel gimnazjalny A. Tyran i inni. W późniejszym okresie redaktorem odpowiedzialnym został Jan Hanszla z Wielkich Piekar (ul. Sobieskiego 19), redakcja zaś mieściła się w Wielkich Piekarach przy ul. 3 Maja w domu Mzyka. Pojedynczy numer kosztowal 20 groszy, a cena prenumeraty miesięcznej wzrosła do 75 groszy.

\footnotetext{
${ }^{112}$ Miejscowość integralnie złączona z Piekarami, zwanymi od chwili przyłączenia do Polski w 1922 r. -Wielkimi. W 1934 r. połączono obie gminy w jeden organizm miejski.

${ }^{113} \mathrm{~W} 1926 \mathrm{r}$. cena prenumeraty wzrosła i wynosiła 75 groszy miesięcznie, a pojedynczy egzemplarz kosztował 20 groszy.

${ }^{114}$ GB 1925, nr 15

${ }^{115} \mathrm{~GB} 1925, \mathrm{nr} 23, \mathrm{z}$ dn. 12.09 .

${ }^{116}$ GB 1925, nr 20, z dn. 22.08 .

${ }_{117} \mathrm{~GB} 1925, \mathrm{nr} 18, \mathrm{z}$ dn. 8.08.

${ }^{118}$ Dodatek do „Głosu z nad Brynicy” $1925 \mathrm{nr} 8 \mathrm{z}$ dn. 30.05.
} 
Czasopismo od chwili powstania borykało się z poważnymi trudnościami finansowymi. Mimo 1600 abonentów redakcja nie mogła normalnie funkcjonować, dlatego prace redakcyjne wykonywano altruistycznie. Czytelnicy wiedzieli o tych trudnościach, dlatego zamieszczając $w$ czasopismie inseraty, zobowiązywali się przysyłać je regularnie ${ }^{119}$. Ponieważ jednak nie wywiązywali się ze swych obietnic, wydawnictwo „Głosu...” kilkakrotnie wystosowywało apel do zarządów gmin z prośbą o ,uchwalenie na... zebraniach... na rzecz dalszego podtrzymywania tygodnika naszego większej kwoty płatnej w każdomiesięcznych ratach na przeciąg pół roku" ${ }^{20}$. Redakcja tygodnika uważała, że w sytuacji, ,gdy wszelkie inne gminy, do których się zwrócono pospieszą z pomocą - natenczas dalszy byt pisma naszego byłby zapewniony"121. Jak się wydaje, najczęściej na apel tygodnika reagowały władze gminy Szarlej. Prawdopodobnie kłopoty finansowe tygodnika wiązały się m.in. ze sposobem jego dystrybucji. Niektórzy czytelnicy bowiem żalili się na zbyt późną dostawę gazety do domu. Dlatego też zespół redakcyjny czynił wiele wysiłków, aby zapewnić dostarczenie „Głosu...” najpóźniej w piątek po południu.

W pierwszym numerze „Głosów...” redakcja powiadamiala czytelników, że bezpartyjny tygodnik będzie „wydawany i pisany przez ludzi żyjących z Wami i mieszkających w-gminach, dla których pismo ma być organem" ${ }^{122}$. Jednocześnie informowała, że tygodnik ma ,zapewnioną współpracę wybitniejszych działaczy i osób uczonych", dlatego zamierza zamieszczać artykuły, omawiające zagadnienia z dziedziny polityki i nauki. W dziale „Korespondencje będzie dana możność do wymiany zdań i polemiki, gdyż każdy z czytelników ma prawo korzystać z łamów naszego pisma i zabierać głos w sprawach lokalnych swej gminy" 123 .

W pierwszym półroczu ukazywania się czasopisma nie zamieszczano w nim ogłoszeń „,urzędu gminnego ( ze stanu cywilnego, czynności policji itp.) i kościelnego" z pobliskiego Radzionkowa, gdzie zamieszkiwali stali abonenci. Dlatego redakcja nie tylko przepraszała mieszkańców tej gminy i parafii, która od XVII w. urządzała piesze i masowe pielgrzymki do Piekar, za brak wymienionych informacji na łamach pisma, ale i przyrzekała radykalną zmianę $w$ tym zakresie, $z$ czego zaczęła się solidnie wywiązywać.

Artykuły w „Głosie...” zamieszczali najczęściej: J. Przybyłek, J. Hanszla, polihistor i badacz przeszłości Śląska K. Prus (pseud. Jacenty Pyrlik) i bliżej nieznani publicyści: ukrywający się pod pseudonimem M. Sas-Tatomir, Zyndrom Mucha ${ }^{124}$, Franciszek Zbozien ${ }^{125}$, Jaxa oraz Obserwator i Iron. Na łamach tego pisma druko-

${ }^{119}$ E. Długajczyk, Oblicze polityczne i wlasnościowe prasy polskiej w województwie ślaskim 1922-1939, Katowice 1990 , s. 89.

${ }^{120}$ Dodatek do Głosu z nad Brynicy 1925, nr 23, z dn. 22.08.

${ }^{121}$ Tamże.

${ }^{122} \mathrm{~GB}$ 1925, nr 1, z dn. 11.04.

${ }_{123}$ Tamże.

${ }^{124}$ Dodatek „Głos znad Brynicy" $1926 \mathrm{nr} 3, \mathrm{z}$ dn. 16.01,

${ }^{125} \mathrm{~GB} 1925, \mathrm{nr} 19, \mathrm{z}$ dn. 15.08 . 
wano również utwory poetyckie ks. K. Damrota, A. Asnyka ${ }^{126}$, J. Lenartowicza, J. Ligonia, ks. A. Skowrońskiego, M. Konopnickiej ${ }^{127}$, a także lokalnych twórców ludowych jak: Maksymilian Jesionowski, ${ }^{128}$ Jadwiga Lempicka ${ }^{129}$, W. Poświt ${ }^{130}$, Adam Pług ${ }^{131}$, Jan Rozum ${ }^{132}$, [N.] Waltycz ${ }^{133}$ czy Maria Gregoracka z Lazisk Górnych. Dla piekarskiego tygodnika sporadycznie pisywał także ks. dr Anastazy Muża ${ }^{134}$. „Głos...” zamieszczał wiele artykułów z życia religijnego sanktuarium maryjnego w Piekarach. Wspominał i szczegółowo opisywał te wydarzenia w parafii piekarskiej, które były celowo fałszowane bądź wyszydzane przez prasę niemiecką, głównie zaś przez „Oberschlesische Kurier”135. Chodzi tu nie tylko o fenomen pobożności polskich Górnoślązaków tłumnie pielgrzymujących do Piekarskiej Pani w przeszłości, ale także o wielowiekowy pietyzm, jakim otaczane było główne sanktuarium Matki Bożej na śląskiej ziemi. Wymieniona niemiecka tzw. gadzinówka szczególnie brutalnie atakowala ks. prałata Wawrzyńca Puchera, ówczesnego kustosza maryjnego sanktuarium w Piekarach. Korzystała $z$ każdej, nawet najbardziej błahej okazji, aby zohydzić i oczernić tego energicznego kapłana. Redakcja „Głosu z nad Brynicy” poczuwała się więc do moralnego obowiązku obrony nie tylko prawdy, ale i niezbywalnych praw ludzkich społeczeństwa polskiego, w tym prawa do wyznawania wiary. $Z$ tego powodu wiele artykułów każdego egzemplarza tygodnika stanowiły artykuły o treści katolickiej i polskiej, co doprowadzało do furii redaktorów niektórych gazet niemieckich, szczególnie zaś często cytowanego „Oberschlesische Kurier”. I tak w zachowanych archiwalnych egzemplarzach „Głosu...” znajdują się opisy przebiegu uroczystości jubileuszu 25 lecia pontyfikatu papieża Leona XIII, które Niemcy podstępem i niezwykłą butą przekształcili w uroczystość wojskową o wybitnie niemiecko-militarnym charakterze, a w której prym wiódł dowódca Kriegervereinu niejaki Schaumkel z Szarleja ${ }^{136}$. Korespondent o kryptonimie „Obserwator” przypominał o dniu poświęcenia kalwarii w Piekarach w 1896 r. zdominowanym przez Niemców hołdujących duchowi imperialistycznemu ${ }^{137}$. W kolejnym numerze pisma przedstawiano wojenne nastro-

${ }^{126}$ Dodatek do ,Głosu z nad Brynicy” 1925, nr 19, z dn. 15.08 .

${ }^{127} \mathrm{~GB} 1925, \mathrm{nr} 19, \mathrm{z}$ dn. 15.08 .

128 Dodatek do „Głosu z nad Brynicy” 1925, nr 15, z dn. 12. 07.

${ }^{129} \mathrm{~GB} 1925, \mathrm{nr} 24, \mathrm{z}$ dn. 19.09.

${ }^{130}$ Dodatek do „Głosu z nad Brynicy" $1925, \mathrm{nr} 9, \mathrm{z}$ dn.5.06.

${ }^{131} \mathrm{~GB} 1925 \mathrm{nr} 23 \mathrm{z}$ dn. 12.09 .

${ }^{132}$ Dodatek do „Głosu z nad Brynicy” 1926, nr 1 z dn.2.01.

${ }^{133} \mathrm{~GB} 1925 \mathrm{nr} 4 \mathrm{z}$ dn. 2.05.

${ }^{134}$ Zob. GB $1926 \mathrm{nr} 34 \mathrm{z}$ dn. 11.10 .

${ }^{135}$ Zob. „Oberschlesische Kurier” 1925, nr 208 z dn. 12.09.

${ }^{136}$ Tamże.

${ }^{137}$ „W pochodzie na powitanie ks. kardynała G. Koppa brały udział różne Krieger-, Victoria-, Gesellen- $i$ inne ferajny. Całe powietrze miało charakter niemiecki, zaledwie na jednej bramie powitalnej był napis polski, arcypasterz do tego ludu nie przemówił ani słówka po polsku, bo niestety nie znał i nie starał się nauczyć języka olbrzymiej części jego diecezjan, rozmowy na probostwie, w zakrystii, pomiędzy księżmi itd. tylko po niemiecku, podczas mszy ani słówka polskiego, honorowi goście - innowiercy, i to wszystko na zie- 
je Niemiec ${ }^{138}$, politykę germanizacyjną, prześladowania Polaków itp. Redakcja zwracała także uwagę czytelników na wydarzenia w Meksyku ${ }^{139}$ i Rosji Sowieckiej, gdzie katolicy byli prześladowani w sposób szczególnie okrutny. W innym artykule historycznym wspominano zasługi byłego wikariusza w Piekarach ks. J. Katrynioka, który w sposób szczególny opiekował się polską młodzieżą zachęcając ją do kultywowania wartości narodowych i religijnych. Do ulubionych tematów redakcji należały wspomnienia dotyczące ks. J. Ficka. To właśnie w nich przytaczano wiele ciekawych szczegółów z życia tego świątobliwego kapłana i społecznika. Jedno z nich, podpisane „Pe. El”, dotyczyło źródeł w miejscowości sanktuaryjnej ${ }^{140}$, a inne - odnowienia kościoła pielgrzymkowego przed koronacją obrazu Matki Bożej cudami słynącego w $1925 \mathrm{r}^{141}$ Jednak najbardziej znany jest okazyjny egzemplarz „Głosu z nad Brynicy” z połowy sierpnia 1925 r., wydany w podwójnej objętości, na kredowym papierze, traktujący o historii sanktuarium, miejscowości, porządku uroczystości koronacyjnej i kultury regionalnej, zawierający także plan sytuacyjny piekarskiej kalwarii. Jednakże leitmotivem tego numeru była uroczystość koronacji obrazu Matki Bożej cudami słynącego. Cena pojedynczego egzemplarza wynosiła 30 groszy. Innym okazyjnym numerem był egzemplarz wydany $z$ okazji powitania bp. A. Lisieckiego w Wielkich Piekarach dnia $30.10 .1926 \mathrm{r}^{142}$ Do stałych rubryk tygodnika należały: $Z$ urzędów stanu cywilnego, $Z$ urzędu meldunkowego i Ostatnie wiadomości. Charakterystyczna dla pisma była żałobna rubryka zatytułowana Umarli dla Polski, będąca wykazem nazwisk 10 renegatów, tj. polskich rodziców posyłających dzieci do szkoły niemieckiej ${ }^{143}$, a więc takich, którzy z różnych względów poddawali się germanizacji i ulegali wynarodowieniu.

Czasopismo miało dwa dodatki składające się na jego stałą objętość: dwustronicowy „Dodatek do «Głosu z nad Brynicy»", który był tematycznie bardzo różnorodny oraz od 1926 r.[?] „Gość Świąteczny. Tygodniowy dodatek bezpłatny”. Ten ostatni liczył cztery strony druku mniejszego o połowę od formatu gazety macierzystej i miał charakter stricte religijny. Zawierał perykopę Ewangelii na niedzielę, dhugi komentarz do niej ${ }^{144}$ oraz opowiadanie religijne dotyczące konkretnego tematu - najczęściej inspirowanego Biblią. Ostatni numer „Głosu...” ukazał się 31. 12. $1926 \mathrm{r}^{145}$, a więc czasopismo utrzymało się na rynku wydawniczym przez niespeł-

mi polskiej wśród polskiego ludu, którego ta uroczystość i to dzieło było zasługa". Cyt. za: GB 1925, nr 24, $z$ dn. 19.09 .

${ }^{138} \mathrm{~GB} 1925, \mathrm{nr} 20, \mathrm{zdn} .22 .08$.

${ }^{139} \mathrm{~GB} 1926, \mathrm{nr} 34, \mathrm{z}$ dn. 11.10 .

${ }^{140} \mathrm{~GB} 1925, \mathrm{nr} 11, \mathrm{z}$ dn. 18.04 .

${ }^{141}$ Dodatek do „Głosu z nad Brynicy” 1925, nr 13, z dn. 3.05? Ten sam artykuł opublikował później diecezjalny „Gość Niedzielny” 1925, nr 17, z dn. 12.07.

${ }^{142}$ Zob. GB 1926, nr 44, z dn. 30.10.

${ }^{143}$ Zob. GB 1925, nr 29, z dn. 24.10.

${ }^{144} \mathrm{~W}$ jednym przypadku redakcja przytoczyła długie kazanie na temat Matki Bożej Bolesnej znakomitego misjonarz ludowego, bardzo popularnego na Górnym Śląsku ks. K. Antoniewicza [Bołoza]. Zob. „Gość Świąteczny” 1926, nr 12, z dn. 20.03.

${ }^{145}$ B. Groeschel (Die Presse Oberschlesiens...) nie wymienia tego polskiego czasopisma. 
na dwa lata ${ }^{146}$. Mimo to odegrało znaczącą rolę $w$ procesie uświadamiania narodowego i religijnego mieszkańców Piekar i okolicy.

\section{0. "PIEKARSKIE WIADOMOŚCI PARAFIAL NE"}

Pierwszy numer „Piekarskich Wiadomości Parafialnych”, wydany z inicjatywy i dzięki staraniom miejscowego proboszcza o „barokowym rozmachu” ks. prałata Wawrzyńca Puchera, ukazał się 13.10.1929 r. jako organ Ligi Katolickiej w Wielkich Piekarach ${ }^{147}$. Stało się to możliwe dopiero po 5 letniej wytężonej pracy skupiającej się na generalnej renowacji całej bazy materialnej sanktuarium maryjnego $\mathrm{w}$ tej miejscowości, wymagającej „niesłychanej ofiarności wiernych i pątników” oraz „wydatnej pomocy Władz Wojewódzkich”148. Czterostronicowe czasopismo $w$ formacie A4, starannie wydawane nakładem Parafialnej Ligi Katolickiej w W.[ielkich] Piekarach, miało ozdobną winietę i było oczywiście tygodnikiem. W winietę tego tygodnika tradycyjnie zgodnie $\mathrm{z}$ lokalnym zwyczajem wkomponowano rysunki trzech medalionów z wizerunkiem Matki Bożej Piekarskiej i sylwetkami dwóch kościołów piekarskich: pielgrzymkowego i kalwaryjskiego. Każdy numer tygodnika rozpoczynał się słowami „Ave Maria!”, nawiązując tym samym do niezmiennego zwyczaju ks. J. Ficka, który każde kazanie, korespondencję urzędową i prywatną rozpoczynał w ten sposób. Te słowa stały w latach 1826-1862 i nie tylko w parafii także zawołaniem o charakterze pozdrowienia. „Piekarskie Wiadomości..." drukowano w miejscowej oficynie wydawniczej Karola Osadnika (który odkupił ją od Teofila Nowackiego w $1919 \mathrm{r} .^{149}$ ), w nakładzie 2500 egzemplarzy. Początkowo redaktorem naczelnym był T. Kubica, za całość prac odpowiadał zaś miejscowy historyk amator, kolekcjoner staroci, kościelny, założyciel i dhugoletni prezes chóru kościelnego $\mathrm{K}$. Cisek ${ }^{150}$, który troszczył się o edycję każdego numeru pisma, aż do chwili zaprzestania wydawania tygodnika w 1939 r. W skład zespołu redakcyjnego wchodzili także miejscowi księża wikariusze: Henryk Ligoń, Robert Seweryn i Aleksander Guzy. Później w redakcji znależli się także ks. Jan Klyczka i oblat Maryi Niepokalanej ks. Jan Pawołek ${ }^{151}$. Zamieszczali oni na łamach pisma głównie krótkie artykuły religijne i formacyjne, troszcząc się także o umieszczenie w tygodniku wszystkich ogłoszeń parafialnych. Celem tygodnika w parafii sanktuaryjnej były: informacja każdej rodziny o porządku nabożeństw, terminach zebrań ponad dwudziestu różnych organizacji stricte religijnych i religijno-społecznych, oraz o ważniejszych wydarzeniach w życiu parafialnym i miejscowości. Natomiast

\footnotetext{
${ }^{146}$ A. Gładysz, Kultura i oświata, [w:] Tarnowskie Góry. Zarys rozwoju powiatu..., s. 243.

${ }^{147}$ Ten tygodnik parafialny nie występuje w: H. Olszar, Duchowieństwo katolickie diecezji ślaskiej (katowickiej) w Drugiej Rzeczypospolitej, Katowice 2000.

148 „Piekarskie Wiadomości Parafialne” [dalej: PWP] 1929, nr 1, z dn. 13.10.

149 J. Pawlik, Piekary Ślaskie, Warszawa 1988, s. 49.

${ }^{150}$ PWP 1929, nr 3, z dn. 27.10.

${ }^{151}$ PWP 1930, nr 6, z dn. 9.02.
} 
część kronikarska miała „przypomnieć czasy przeszłe już dawno i uprzytomnić [...] obyczaje i dzieje [...] przodków"152.

„Piekarskie Wiadomości...” w zamyśle kustosza sanktuarium miały docierać bezpłatnie ${ }^{153}$ do każdej piekarskiej rodziny dzięki młodym ochotnikom - kolporterom $^{154}$. Zespół kolporterów z zasadzie nie zmieniał swego składu osobowego. Jego członkowie docierali do wyznaczonego rejonu parafii ${ }^{155}$ i wręczali bezpłatny egzemplarz tygodnika każdej rodzinie, nawet niezbyt związanej z Kościołem. Niektórzy abonenci wręczali kolporterom drobną sumę pieniędzy, co niezbyt podobało się niektórym duchownym i parafianom. Wcześniej bowiem zapowiedziano, że po każdej Mszy św. niedzielnej ministranci przed świątynią będą zbierać do skarbonek dobrowolne ofiary na druk czasopisma. Dlatego już w 1930 r. kolporterzy: Łucja Nowak, Agnieszka Gawron, Maria Nowak, Maria Kubowska, Śrót, Kossek, Gałbas, Ogiewa, Fonfra, Apolonia Hojka, Eryk Zosgórniok, Andrzej Pucher, Adamczyk, Wandzik i Maruszczyk byli zaopatrzeni w specjalne skarbonki, do których można było składać dobrowolne datki. „Piekarskie Wiadomości...” można było też nabywać w zakrystii. Wszelkie prace redakcyjne były wykonywane honorowo $\mathrm{i}$ bezpłatnie. Ten tygodnik parafialno-sanktuaryjny - jak zapowiadał artykuł wstępny - nie miał zastępować diecezjalnego tygodnika „Gość Niedzielny”, lecz jedynie „torować mu drogę". Od numeru 2 z 1929 r. ogłoszenia parafialne, na prośbę bardzo nielicznej ale krzykliwej mniejszości niemieckiej, podawano w języku polskim i niemieckim, co znacznie skracało czas nabożeństw. Każdy kolejny egzemplarz tygodnika zamieszczał także Komunikaty Parafialnej Ligi Katolickiej, Kronikę Parafialnq i artykuł formacyjny. Tak zwane ogłoszenia pośmiertne (nekrologi), podziękowania, anonse i ogłoszenia zebrań świeckich towarzystw umieszczano w tygodniku za drobną opłatą ${ }^{156}$.

Rozbudowany dział ogłoszeń tygodnika dokumentował życie religijno-społeczne parafii w Piekarach Wielkich. I tak: miejscowa Liga Katolicka urządzała nie tylko statutowe zebrania, na których omawiano ,zadany” przez centralę temat, ale prowadziła także kursy gry na mandolinie, kurs fotograficzny, bibliotekę historyczną, ze szególnym uwzględnieniem dziejów regionu ${ }^{157}$. $Z$ ambony do wiernych przemawiało wielu zaproszonych mistrzów słowa, m.in. o. superior Kulawy z Kodnia, ks. Jan Grabowski wracający z Rzymu do Sompola, oraz misjonarz pochodzący z Piekar Józef Chnicki ${ }^{158}$. W pierwszej dekadzie listopada 1929 r., po kilkumiesięcznej przerwie, wznowiło dzialalność zasłużone Kasyno Katolickie, krzewiące

\footnotetext{
${ }^{152}$ Odezwa ks. pratata W. Puchera, PWP 1929, nr 1, z dn. 13.10.

${ }^{153}$ Od numeru 5. z 1929 r. kolporterzy roznosili tygodnik, zbierając za to ofiary do skarbonek.

${ }^{154}$ Miesięczny druk „Piekarskich Wiadomości..." kosztował parafię $600 \mathrm{zl}$.

${ }^{155}$ Do 1931 r. do parafii sanktuaryjnej należały miejscowości: Piekary [Wielkie], Szarlej oraz wieś Jó-
} zefka.

${ }^{156}$ PWP 1930, nr 40, z dn. 5.10.

${ }^{157}$ PWP 1929, nr 2, z dn. 20.10.

${ }^{158}$ PWP 1929, nr 3, z dn. 27. 10. 
w miejscowości i parafii idee polskości i katolicyzmu ${ }^{159}$. Redaktorzy często przedstawiali ofiarność parafian i pielgrzymów, informując o wielkości kwoty zebranej na cele kościelne. Stowarzyszenie Młodzieży Polskiej chlubiło się wynikami sportowymi niektórych swych członków w zawodach różnej rangi. Inni działacze parafialni uświadamiali czytelnikom przywilej społeczności parafialnej polegający na emitowaniu nabożeństw drogą radiową, co rozsławiło parafię w Wielkich Piekarach, nawet na Kresach Wschodnich ${ }^{160}$. Dzięki temu wielu ofiarodawców z całej Polski składało dobrowolne datki na odrestaurowanie i utrzymanie miejscowej kalwarii. W kolejnym numerze tygodnika wymieniono wszystkie róże rożańcowe, tj. grupy modlitewne modlące się na różańcu ${ }^{161}$. Z lektury innych egzemplarzy „Piekarskich Wiadomości..." można poznać historię działalności Kongregacji Panien, oddziału młodszego Stowarzyszenia Młodzieży Męskiej ${ }^{162}$, Komitetu Towarzystwa Czytelni Ludowych ${ }^{163}$, a nawet przebieg wyborów do rady gminnej, do Senatu Rzeczypospolitej ${ }^{164}$ i Akademii Papieskiej ku czci Piusa XI ${ }^{165}$. Na łamach „Piekarskich Wiadomości..." zamieszczano także repertuar filmów religijnych wyświetlanych w miejscowym kinie „Helios”, bardzo często zapraszano na przedstawienia teatralne urządzane przez amatorską grupę złożoną z członków miejscowych organizacji religijnych-i narodowych. Każdy numer czasopisma prowadził rubrykę na temat statystyki parafialnej, $\mathrm{w}$ której wymieniano ( $\mathrm{z}$ odpowiednim numerem porządkowym) zapowiedzi ślubne, chrzty i pogrzeby. Z początkiem marca $1932 \mathrm{r}$. „Piekarskie Wiadomości...” podjęły publikację długiego cyklu artykułów na temat sakramentów świętych, a w dwóch następnych latach -obszerny i praktyczny komentarz do Katechizmu. W ten sposób tygodnik zmienił swój profil na pismo religijno - formacyjne. Zaniechanie publikacji artykułów historycznych niewątpliwie mocno zubożyło pismo. Wynikało to - jak się wydaje - $z$ braku czasu potrzebnego na ich opracowanie przez nielicznych autorów, w tym znanego historyka śląskiego ks. dr. J. Knosały, kościelnego K. Ciska, kierownika [szkoły?] T. Kubicy i „Starzyka". Natomiast zamieszczanie artykułów katechizmowych niewątpliwie wzmocniło oddziaływanie duszpasterskie w okresie powszechnego strachu przed zbliżającą się wojną. „Piekarskie Wiadomości Parafialne” ukazywały się do 6.08.1939 r., tj. do chwili bandyckich napadów policji niemieckiej na raciborską „Strzechę" - siedzibę organizacji polskich - i wszczęcia akcji relegowania z Uniwersytetu Wrocławkiego ostatnich studiujących tam Polaków oraz opieczętowania przez gestapo jedynej we Wrocławiu polskiej szkoły podstawowej, tzw. Szkółki.

\footnotetext{
${ }^{159}$ PWP 1929, nr 5, z dn.10.11.

${ }^{160}$ PWP 1929, nr 6, z dn. 17.11; 1930, nr 6, z dn. 9.02.

${ }^{161}$ PWP 1929, nr 7, z dn. 24.11.

${ }^{162}$ PWP 1930, nr 1, z dn. 5.01.

${ }^{163}$ PWP 1930, nr 48, z dn. 30.11.

${ }^{64}$ PWP 1930, nr 50, $\mathrm{z}$ dn. 14. 12.

${ }^{165}$ PWP 1930, nr 8, z dn. 23.02.
} 
11. „NOWINY. PISMO POŚWIECONE SPRAWOM LOKALNYM. TYGODNIK NA SZARLEJ I W. [IELKIE] PIEKARY ORAZ POWIAT TARN. [OWSKIE] GÓRY"

Tygodnik ten nie był wydawany w Wielkich Piekarach, chociaż integralnie łączył się z życiem społecznym tej miejscowości pielgrzymkowej, która w latach 30 . $\mathrm{XX}$ w. była miejscem licznych, masowych i thumnych manifestacji religijno-patriotycznych o zasięgu lokalnym, wojewódzkim (diecezjalnym) i ogólnopolskim, organizowanych bądź to przez stronę kościelną, bądź to przez władze państwowe.

Pierwszy numer czasopisma, ukazał się w wigilię Bożego Narodzenia $1930 \mathrm{r}$. w Tarnowskich Górach. Podtytuł informował, że jest to ,pismo poświęcone sprawom lokalnym". Obok skromnej winiety zamieszczono informację o tym, że adresatami pisma są mieszkańcy Szarleja, Wielkich Piekar oraz powiatu Tarnowskie Góry ${ }^{166}$. Redakcja i administracja „Nowin” mieściła się w „Hotelu pod Lipami” w słynnym mieście gwarków na Rynku pod numerem 13. Właściciel hotelu Juliusz Kapuściok pofrafił umiejętnie wykorzystać fakt istnienia redakcji czasopisma w swoim lokalu. Jego inseraty reklamujące „Hotel pod Lipami” umieszczane w „Nowinach” informowały zatem, że serwuje się w nim wyśmienite „obiady i kolacje”, a „bufet zađpatrzony jest w zimnie i gorące zakąski”. W hotelu można wypić „,dobrze pielęgnowane piwa tyskie”, a z najbliższego przystanku odjeżdżają autobusy w „kierunku Katowice, Woźnik i Bytomia”. Ponadto wszelkie usługi hotelowe zamawiać można telefonicznie (numer telefonu 1124 w Tarnowskich Górach). Pierwszy numer „Nowin” wydrukował - jak wynika z badań E. Dhugajczy$\mathrm{ka}^{167}$ - „Winfryd Paweł Gruszka, były komisarz Straży Granicznej, przedwcześnie emerytowany $z$ powodu nadużywania alkoholu i zapewne działalności politycznej w separatystycznyn Związku Obrony Górnoślązaków... u Mariana Całki, przy ulicy Barbary 1" 168 . Ekskomisarz deklarował w artykule wstępnym, że: „Stale stać będziemy ponad waśniami i kłótniami partyjnymi i ugrupowań społecznych. Łamy nasze otwieramy ze staropolską gościnnością dla wszystkich miejscowych polskich towarzystw kulturalno-oświatowych, stojących na niewzruszonych zasadach chrześcijańskich i państwowych. (...) Stale donosić będziemy o uchwałach miejscowej rady miejskiej i gminnej, uważając bowiem słusznie, że i te sprawy interesują wszystkich. Często zdarzają się wypadki, że z powodu nieznajomości ustaw komunalnych i państwowych dużo obywateli ulega karze, przeto i te sprawy umieszczać będziemy na łamach «Nowin»" 169 .

Cena pojedynczego egzemplarza „Nowin” wynosiła 25 gr., a przedpłata miesięczna $z$ „dostawą do domu 1 złoty”, potem 1,50. Początkowo ,za 3 łamowy wiersz [reklamy] mm" należało zapłacić 25 gr., inne ogłoszenia były płatne we-

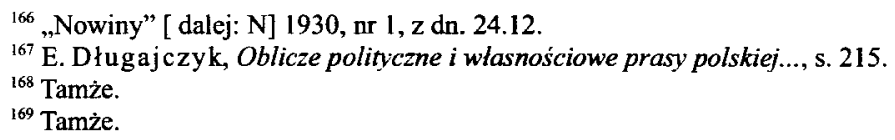


dhug umownej stawki ${ }^{170}$. W drugim roku edycji pisma, stawki te wzrosły trzykrotnie. Ponieważ czasopismo to przejęło (po śmierci w dniu 14.01.1931 r. Konstatnego Lipskiego, współwłaściciela „Tygodnika na Powiat Tarnogórski” ${ }^{171}$ ) abonentów gazety Lipskiego, początkowo rozwijało się dobrze. Od marca $1931 \mathrm{r}$. ukazywało się dwa razy w tygodniu, a od września $1932 \mathrm{r}$ - - trzy razy w tygodniu ${ }^{172}$. Ze względu na poszerzoną kolumnę wiadomości lokalnych, obejmującą od kwietnia 1932 r. także powiat lubliniecki, podtytuł „Nowin” brzmiał: „,czasopismo północnej części województwa śląskiego". Zasługą Gruszki, redaktora naczelnego „Nowin” było skompletowanie dynamicznego zespołu współpracowników. W jego skład weszli: wychowanek W. Hajdy Jan Hanszla, Florian Skiba, Franciszek Kaczmarek, Wiktor Osyra, Jan Lokiecz i były redaktor „Katolika” Walenty Tyczka. Ukazywali oni wydarzenia społeczno-polityczne i religijno-kulturalne regionu na tle ważnych wydarzeń europejskich, a nawet światowych. Przedstawiały zatem m.in. „Hoovera jako dyktatora Europy"173, zabiegi Niemców "chcących zdławić import towarów zagranicznych" 174 Radę Ligi Narodów i jej działalność „w sprawie wojny chińsko-japońskiej”"175, „podróż ministrów francuskich do Berlina”, „największą drogę wodną w Czechosłowacji” ${ }^{\prime 176}$, a jednocześnie informowały o objęciu posady wicestarosty powiatu świetochłowickiego przez Józefa Korola, o kredytach na budowę domów drewnianych, obniżkach komornego, wizycie ks. kard. A. Hlonda na wystawie Hallerczyków w Poznaniu w lipcu 1931 r., projektach urządzenia ogrzewalni [w Tarnowskich Górach] dla biednych i wielu innych małej wagi sprawach. Gazeta posiadała specyficzny „Dodatek ilustrowany do Nowin”"177, o którym niewiele wiadomo. Na jego treść składały się m.in. rysunki (w liczbie 12) przedstawiające wydarzenia o różnym charakterze. Dotyczyły one np.: 10-lecia sakry łódzkiego biskupa W. Tymienieckiego; otwarcia wystawy znanego malarza amerykańskiego Mr. Herzoga, który ukończył setny rok życia; zdetronizowanego w 1912 r. cesarza chińskiego Pu Yi, pretendującego do korony w Mandżurii; meczu piłkarskiego Warszawianki z Wartą zakończonego wynikiem 2:1; tradycyjnego obowiązku nowowybranego burmistrza Londynu gotowania pudingu ${ }^{178} \mathrm{i}$ in. „Nowiny” były czasopismem popularnym na miarę ówczesnych możliwości i oczekiwań czytelniczych. Nie zadając sobie trudu spełniania wyższych zadań eduakcyjnych, skłaniały się jednak ku ugruntowaniu w swych odbiorcach idei polskości i katolicyzmu ${ }^{179}$. W 1933 r. częstotliwość edycji pisma zmieniła się kolejny raz: pismo wychodziło

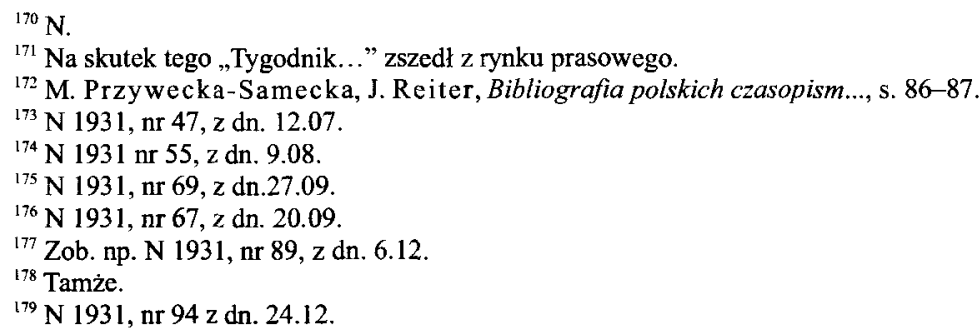


we wtorki, czwartki i soboty. Opłata miesięczna z dostawą do domu wynosiła 1,50 zł, a cena pojedynczego egzemplarza - 15 gr. Lam reklamy kosztował 0,20 gr, cena większej reklamy była uzgadniana. Pismo liczyło cztery strony druku; podzielono je na kilka szpalt (od 4 do 6). Ostatnia strona przeznaczona była wyłącznie na inseraty zapewniające bardzo nikły dochód ${ }^{180}$. Redakcja i administracja czasopisma mieściła się nadal w Rynku w Tarnowskich Górach. Redaktorem odpowiedzialnym był J. Mainka, a redaktorem w Radzionkowie - W. Tyczka, za dział sportowy zaś odpowiadał Olesch. Wydawcą pisma była Drukarnia Polska w Tarnowskich Górach. Na treść „Nowin...” składały się głównie artykuły informacyjne dotyczące: polityki, spraw wojskowych, techniki, problemów rencistów, bezrobotnych, związków akademickich, spraw społecznych, ciekawych afer i nadużyć gospodarczych. Rzadziej drukowano wiersze lokalnych lub regionalnych autorów, np. Leona Kloca.

Od 1.05. 1933 r. „Nowiny” weszły na rynek czytelniczy z bliźniaczym czasopismem pt. „Gazeta Szarlejsko-Piekarska”. Nakład tego pisma ukazującego się z przerwami wynosił tylko 200 egzemplarzy. Z powodu nikłego bądź wręcz kompletnego braku zainteresowania nią „Gazeta Szarlejsko-Piekarska” została zlikwidowana ${ }^{181}$. Według niektórych badaczy „Nowiny” ukazywały się przez cztery lata - do 1933 r. ${ }^{182}$, zdaniem innych zaś do 25.03 .1937 r. Od numeru 1(32) z 1937 r. czasopismo przekształciło się w „Gazetę Piekarską”.

\section{2. "GAZETA PIEKARSKA"}

Nazwę czasopisma „Gazeta Piekarska” odnotowano w Bibliografii polskich czasopism ślaskich (do 1939 roku) M. Przyweckiej-Sameckiej i J. Reitera pod numerem 156. Czasopismo liczyło 4 strony druku dużego formatu $-32 \mathrm{~cm} \times 48 \mathrm{~cm}$. Ukazywało się dwa razy w tygodniu, tj. w środę i w sobotę. Uchodziło za klasyczny póltygodnik adresowany głównie do mieszkańców gmin Szarlej i Piekary Wielkie, które w 1934 r. zostały połączone w jedną gminę pod nazwą Szarlej-Piekary Wielkie, a w 1935 r. przemianowane na Piekary Śląskie ${ }^{183}$, oraz obywateli Tarnowskich Gór i sąsiednich miejscowości. Pierwszy numer „Gazety Piekarskiej” ukazał się najprawdopodobniej w 1937 r. Cena pisma wynosiła 15 groszy $^{184}$, a przedpłata miesięczna 1 zł i 20 groszy. Wydawcą pisma była M.[aria?] Skrodzka, a redaktorem odpowiedzialnym - Zygmunt Skrodzki, oboje z Tarnowskich Gór. Czasopismo drukowano w Zakładach Graficznych i Wydawniczych „Nowiny” w Tarnowskich Górach, Rynek 13. Tam też - jak wynika $\mathrm{z}$ informacji zamieszczonej pod podtytu-

\footnotetext{
${ }^{180}$ Nakład „Nowin..." miał liczyć ok. 200 egzemplarzy.

${ }^{181}$ E. Długajczyk, Oblicze polityczne i wlasnosiciowe prasy polskiej..., s. 219.

${ }^{182}$ W zasobach Biblioteki Jagiellońskiej znajdują się następujące egzemplarze „Nowin": R. 1: 1930, nr 1, R. 2: 1931, nr 1-92 (brak nr 33, 36, 37), R. 3: 1932, nr 1-119 (braki), R. 4: 1933, nr 1-36 (braki).

${ }^{183}$ Tarnowskie Góry. Zarys rozwoju miasta i powiatu.... s. 560 . Inne daty występują w monumentalnej pracy pt. Nazwy geograficzne Ślqaska, red. S. Sochacka, t. 10: Pato-Poz, Opole 2002, s. 32.

${ }^{184}$ Od połowy listopada 1937 r. do połowy stycznia 1938 r. cena egzemplarza wynosila tylko 10 groszy.
} 
łem - mieściła się redakcja, natomiast przy administracji podawano inny adres: Piekary Śląskie, ul. Marszałka Piłsudskiego 2, m. 8. Półtygodnik ten drukowany był aż do wybuchu II wojny światowej ${ }^{185}$.

Układ treści „Gazety Piekarskiej” był niezmienny. Na pierwszej stronie zamieszczano artykuł odredakcyjny, którego treść opierała się na stereotypowym haśle: uświadomiony narodowo Polak - głęboko wierzący katolik. Czasopismo ukazywało poprawę i to pod każdym względem, sytuacji wewnętrznej kraju ${ }^{186}$, oraz bardzo niekorzystne kształtowanie się warunków zewnętrznych państwa, a więc pogarszanie się położenia międzynarodowego Polski. Główne niebezpieczeństwo zdaniem redaktorów „Gazety Piekarskiej' - stanowiły Niemcy hitlerowskie, które intensywnie rozwijały przemysł zbrojeniowy, stale nawiązując do koniecznej ich zdaniem rewizji traktatu wersalskiego. „Gazeta Piekarska” uświadamiała też czytelnikom pasywną politykę mocarstw europejskich i (w znacznie mniejszym zakresie) zamorskich, co sprzyjało Niemcom. Po zajęciu strefy zdemilitaryzowanej w Nadrenii Niemcy dokonały Anschlusu (połączenia) Austrii z Rzeszą, potem hitleryzacji Gdańska, co niestety nie spotkało się z ostrą reakcją ze strony Polski. Bierność państw demokratycznych zachęcała wręcz Niemców do dalszej ekspan$\mathrm{sji}^{187}$. Te aspekty polityki europejskiej redakcja ukazywała przez pryzmat krótkich i nielicznych informacji, zamieszczanych także na pierwszej stronie każdego egzemplarza pisma.

Druga strona „Gazety Piekarskiej” ukazywała „Polskę w przekroju” oraz życie religijno-społeczne miejscowości pielgrzymkowej - Piekar Śląskich. Podkreślano tutaj siłę moralną i żywotność tradycji Kościoła katolickiego. Zachęcano czytelników do masowego uczestnictwa we wszystkich ważniejszych uroczystościach religijnych. Z kolei opisywane na lamach „Gazety Piekarskiej” uroczystości kościelne oddawały rolę Kościoła podczas masowych imprez rocznicowych, a więc swoisty rytual, jak w trakcie pielgrzymek i ludnych manifestacji patriotycznych w Piekarach Śląskich. Nawiązywano do wydarzeń historycznych z życia Kościoła i państwa polskiego ${ }^{188}$. Stanowiły one „powtórki” ponawianych od wieków form kultu, wielokrotnie sprawdzonych jako te, które spełniają oczekiwania ludzi wierzących. W „Gazecie Piekarskiej” zamieszczano też porządek nabożeństw kościelnych w sanktuarium maryjnym, przypominano o świętach kościelnych, zachęcając wierzących, a także wszystkie organizacje „świeckie i kościelne ze sztandarami” do licznego w nich udziału. Czasopismo nie tylko informowało o zebraniach bractw i stowarzyszeń katolickich, ale także podawało ich cel, a więc „porządek dzienny", koordynując tym samym działalność licznych organizacji społecznych, kulturalnych, religijnych, narodowych i patriotycznych w Piekarach Śląskich, Tar-

\footnotetext{
${ }^{185}$ A. Gładysz, Kultura i oświata, [w:] Tarnowskie Góry. Zarys rozwoju powiatu., dz. cyt., s. 243.

${ }^{186}$ Zob. ,Gazeta Piekarska [dalej: GP] 1937, nr (93) 62, z dn. 30.10; (95) 64, z dn. 6.11.

${ }^{187}$ GP 1938, nr 16, z dn. 26.02.

${ }^{188} \mathrm{GP} 1937,(97) 66, \mathrm{z}$ dn. 13.11 .
} 
nowskich Górach i okolicy. Sprawy społeczne pojawiały się również na kolejnej, trzeciej stronie czasopisma, gdzie prezentowano działalność różnych lokalnych urzędów, miejscowych instytucji, organizacji użytku publicznego, jak np.: służby granicznej, celnej, policji, straży ogniowej, poczty i kasy oszczędnościowej, lokalnych szkół, kin, sklepów, a także imprez sportowych, głównie meczów piłkarskich itd. Nie wahano się informować o niektórych wybrykach dzieci i młodzieży, co miało shużyć celom wychowawczym. Ostatnia strona pisma przeznaczona była na reklamy i inseraty.

Bardzo ważnym problemem analizowanym na łamach „Gazety Piekarskiej” była działalność Związku Nauczycielstwa Polskiego, wzbudzająca polemikę i niepokój w społeczeństwie ${ }^{189}$. Licząca ponad 50 tys. członków organizacja, została bowiem „opanowana" przez lewicę ,jednofrontową" ${ }^{190}$ i zacierała różnice między „socjalizmem a agenturalnym komunizmem" "191. Zdobyła sobie spore wpływy w społeczeństwie, przedstawiając niezgodnie $z$ rzeczywistością sytuację społeczno-polityczną i kulturalno-gospodarczą w ZSRR. Nadużycia różnej natury, które stały się niejako znakiem firmowym tej organizacji ${ }^{192}$, doprowadziły do przydzielenia jej we wrześniu 1937 r. kuratora rządowego. Mimo to sprawa tzw. funduszu wdów i sierot im. sen.[atora] Nowaka dała nowy asumpt do powstania dysonansu w życiu społeczno-politycznym Rzeczypospolitej ${ }^{193}$. Okazało się bowiem, że spora część społeczeństwa podatna jest na demagogię organizacji, która prezentowała kraj wschodniego sąsiada jako raj na Ziemi. W ten nurt „,nagłaśniany” przez „Gazetę Piekarską" wpisywał się także artykuł pt. Jak Ukraińcy rutenizuja żywiot polski w Malopolsce Wschodniej $?^{194}$ i wiele innych publikacji prasowych, nakazujących nie tylko rozważną obserwację wschodniego sąsiada, ale doprowadzając też do radykalizacji nastrojów społecznych.

Jeden z egzemplarzy „Gazety Piekarskiej” z dnia 27.11.1937 r., sygnowany numerami (100) 70, zwiększył swoją objętość do 8 stron druku, ponieważ zawierał również okolicznościowe, aktualne fotografie. Powód tego zabiegu wydawniczego i redakcyjnego wyjaśnił artykuł wstępny pt. Przemysł Tarnogórski - Armii. Wyjaśniono w nim, że „Rzadko zdarzają się momenty, rzadko bywają chwile, kiedy razem z żołnierzem polskim kroczy obywatel, owiany życiem «cywila». A gdy taka chwila nadejdzie, (...) to kroczących w szeregu żołnierzy ogląda zaledwie część społeczeństwa [...], którym splotem okoliczności dane jest zamieszkać w mieście, w którym stacjonowany jest ułomek naszej dzielnej i poteżnej Armii". Zdaniem redakcji „Gazety Piekarskiej”, szczególnym miesiącem dla mieszkańców Radzionkowa, miejscowości sąsiadującej i z Tarnowskimi Górami i z Piekarami Śląskimi, był

\footnotetext{
${ }^{189}$ GP 1937, nr (95) 64, z dn. 6.11.

${ }^{190}$ GP 1937, nr (97) 66, z dn. 13.11.

${ }^{191}$ Por. A. Albert [W. Roszkowski], Najnowsza historia Polski 1914-1993, t. 1, Londyn 1994, s. 326.

${ }^{192}$ GP 1937, (98) 67, $\mathrm{z}$ dn. 17.11.

${ }^{193}$ GP 1937, (99) 68, z dn. 20.11.

${ }^{194}$ GP 1937 (102) 72, z dn. 4.12.
} 
listopad 1922 r., gmina Radzionków bowiem ,zadzierżgnęła [wtedy] miłość z żołnierzem polskim, który stanął na straży tego, co dla nas jest drogie i święte". $\mathrm{Z}$ tego powodu robotnicy rozwijających się zakładów The Henckel von Donnersmarck, świadomi agresywnej polityki niemieckiej, ufundowali polskiej armii 3 karabiny maszynowe i 2 granatniki, dołączając w ten sposób do podobnych ,darów" ufundowanych przez liczne podmioty gospodarcze całej Rzeczypospolitej. Podarunek wręczono 14.11.1937 r. w trakcie uroczystości na miejscowym stadionie sportowym, w obecności władz wojewódzkich, powiatowych i lokalnych ${ }^{195}$. Dwustronicowy artykuł na ten temat zawierał fotografie: starosty tarnogórskiego mgr. Pawła Mierzwy, pułkownika Gorgonia z garnizonu tarnogórskiego, naczelnego dyrektora Zakładów The Henckel von Donnersmarck w Tarnowskich Górach Jana Bogusława Kuryłowicza, który jednocześnie był dyrektorem Zakładów Chemicznych Hugohiitte w Czarnej Hucie, wizerunek aktu wręczania nowej broni żołnierzom, korpusu oficerskiego z Tarnowskich Gór oraz ołtarza polowego. Pozostałe strony pisma traktowały o życiu narodowym i kulturalno-gospodarczym Radzionkowa, Tarnowskich Gór i Piekar Śląskich.

W tej samej objętości (8 stron) ukazał się egzemplarz „Gazety Piekarskiej” w dniu 26.02.1938 \&., który otwierał artykuł wstępny pt. Budżet Tarnowskich Gór jest zrównoważony $i$ realny. Uzasadnienie p. burmistrza Antesa. Ukazywał on funkcjonowanie instytucji i służb miejskich, a także konieczność podjęcia nowych inwestycji w mieście służących ludności. Szczególną uwagę skoncentrowano na rozwoju infrastruktury miejskiej, tj.: szkół, żłobków, przedszkola i dróg. Jednak najwięcej emocji czytelników wzbudzała sprawa zaopatrzenia w wodę, której stan zużycia nieustannie wzrastał. Kolejne artykuły omawiały m.in. korzyści wynikające z przynależności rolników do izby rolniczej, ze spraw lokalnych, w tym także nadużywania władzy przez lokalnych urzędników, przebiegu Święta Papieskiego w Rybnej (dziś: Strzybnica), życia religijno-społecznego w Piekarach Wielkich oraz funkcjonowania różnych instytucji, urzędów i organizacji różnego typu w kilku miejscowościach.

W innych numerach piekarskiego czasopisma z lat 1938 i 1939 sporo miejsca przeznaczono na analizę chwiejnej sytuacji politycznej Polski, która opierała swoją politykę zagraniczną na koncepcji równorzędnych stosunków z Niemcami i ZSRR. Formalnie poprawne stosunki z Berlinem i Moskwą teoretycznie podnosiły prestiż Polski, ale nie sprzyjało to - jak się później okazało - samej Rzeczypospolitej. Ocena sytuacji wewnętrznej Polski i stosunków międzynarodowych en gros były

195 „Uroczystość przekazania «upominku» rozpoczęło nabożeństwo polowe, odprawiane przy ołtarzu, ustawionym na stopniach trybuny [honorowej], obok którego zasiedli przedstawiciele władz wojskowych i cywilnych... Po nabożeństwie przemówił ks. Pawlak, który w pięknych słowach podkreślił, że Polska zawsze wysoko dźwigała godło Chrystusa i godło Rzeczypospolitej, zaczynając każdą sprawę w imię Boga i z Bogiem. Ks. prob. Pawlak przytoczył słowa Jana Długosza, który człowieka nie przynoszącego Rzeczypospolitej upominku nazwał czlowiekiem nikczemnym. Toteż górnicy Radzionkowa - mówił kaznodzieja - nie chcą pozostać w tyle, niosą dzisiaj Ojezyźnie taki upominek, na jaki ich było stać!" 
prezentowane przez to czasopismo poprawnie i adekwatnie do rzeczywistości. Dlatego też gazeta ta mogła przyczynić się do właściwego kształtowania świadomości patriotyczno-religijnej ponadlokalnego społeczeństwa tej części Górnego Śląska ${ }^{196}$. Zważywszy na nieliczny skład osobowy redakcji, aspekt ten należy szczególnie podkreślić.

„Gazeta Piekarska” miała kilka bezpłatnych dodatków niedzielnych. Nie wiadomo jednak, ile ich numerów wyszło spod prasy drukarskiej. Cechą charakterystyczną było to, że na jednym arkuszu drukarskim o objętości czasopisma macierzystego drukowano aż trzy dodatki razem. Były to: „Rodzina”, „Gospodarz” oraz „Ilustrowany Kurier Kobiecy”. Ponadto między nimi, na stronie trzeciej, umieszczano obszerny dział pt. Niedziela na wesolo niejako czwarty dodatek. Zawierał on powieść w odcinkach bardzo poczytnego wówczas pisarza Antoniego Ossendowskiego ${ }^{197}$ pt. Matka. Wszystkie dodatki „Gazety Piekarskiej” wzbogacane były obfitym materiałem ilustracyjnym. Z bliższych badań może wynikać, że „dodatek [do „Gazety Piekarskiej”] pojawiał się przez kilka miesięcy w 1938 r. i był tworem obcym, prawdopodobnie nabywanym w Zakładach Wydawniczych Alfreda Ksyckiego w Żninie, które zamieszczały go w «llustrowanym Kurierze Pałuckim»" ${ }^{198}$.

Pod koniec 1937 r. bądź na początku 1938 r., kiedy czasopismo ciągle składało się z 8 stron, dodatek stanowiły „Wiadomości Parafialne”. W ten sposób jedna karta czasopisma macierzystego przekształcana była w 4 strony gazetki kościelnej. „Wiadomości Parafialne" redagował - jak wynika z tzw. stopki - Katolicki Urząd Parafialny [parafii pod wezw. Św. Piotra i Pawła ${ }^{199}$ ], a redaktorem odpowiedzialnym był Leon Grabiec z Tarnowskich Gór. Przewodniczącym zespołu redakcyjnego [ formalnie] był ks. Michał Lewek ${ }^{200}$. Od tego też czasu „Gazeta Piekarska” adresowana była w całości do mieszkańców Tarnowskich Gór i najbliższej okolicy. Z miejscowością sanktuaryjną łączył ją teraz wyłącznie tytuł oraz nieliczne artykuły dotyczące pielgrzymek do Piekar Wielkich.

Wyjaśnienia wymagają kwestie dotyczące wydawania w Niemieckich Piekarach w latach 1851-1853 Poradnika Górnośląskiego, który - według cenionej

${ }^{196}$ Zob. GP 1937, 1938. Biblioteka Śląska w Katowicach, sygn. 269118 IV.

${ }^{197}$ A. Ferdynand Ossendowski (1878-1945), pisarz, chemik, wykładowca, podróżnik, publicysta, pracownik shuzb specjalnych [?], konsultant w sprawach przemysłu wojennego, doradca ministrów, na przełomie lat 30. ub. wieku byl jednym z najpopularniejszych i najlepiej zarabiających pisarzy polskich. Zob. PSB, t. 24, s. 381-385.

${ }^{198}$ E. Długajczyk, Oblicze polityczne i własnościowe prasy polskiej..., dz. cyt., s. 221.

${ }^{199}$ W tym okresie w Tarnowskich Górach funkcjonowała formalnic tylko jedna parafia, chociaż w miejscowości funkcjonowały także inne obiekty sakralne, jak: zabytkowy kościół św. Anny na starym cmentarzu, kaplica publiczna w zakładzie leczniczym ojców kamilianów (Ordo Clericorum Regularium Ministrantium Infirmis) na tzw. Galgenbergu oraz Konwikt Biskupi.

${ }^{200}$ H. Olszar, Duchowieństwo katolickie diecezji ślaskiej..., dz. cyt., s. 606. 
i znanej Bibliografii polskich czasopism ślaskich (do 1939 roku) M. Przyweckiej Sameckiej i J. Reitera (Wrocław 1960) - miał być redagowany przez ks. J. Ficka, proboszcza i kustosza sanktuarium maryjnego w Niemieckich Piekarach, a wydawany był przez pierwszego drukarza osiadłego w tej miejscowości T. Heneczka w latach 1851-1853 $3^{201}$. Tymczasem odnotowane pod numerem 578. cytowanej $B i$ bliografii... czasopismo, zdaniem innych prasoznawców - najprawdopodobniej nie było efemerydą ${ }^{202}$. $Z$ tym czasopismem - matką lączą oni bowiem dwie kolejne efemerydy - Dodatek "Poradnika Górnośląskiego", który miał być wydawany w Niemieckich Piekarach, oraz Ciąg Dalszy „Poradnika Górnośląskiego”. Także te czasopisma miały się ukazywać w miejscowości sanktuaryjnej w 1854 r. Nakładcą obu gazet prawdopodobnie mógł być K. Kosicki, a wydawcą T. Heneczek w Niemieckich Piekarach. O ile nazwisko nakładcy, tj. Karola von Koschiitzkiego (Kosickiego) z Wielkich Wilkowic, który bardzo słabo lub w ogóle nie władał językiem polskim, (jego artykuły na język polski tłumaczyli J. Lompa i E. Smołka) nie budzi większych wątpliwości, (życiorys tego wydawcy opublikował ks. J. Kudera w Obrazach Ślazaków wspomnienia godnych ${ }^{203}$ ) o tyle rodzą się poważnie zastrzeżenia w stosunku do faktycznego istnienia dwóch efemeryd, jakoby związanych z Poradnikiem Górnoślaskim, których istnienia nie można potwierdzić.

Można być bowiem pewnym tylko tego, że na pewno istniał inny dwumiesięcznik, redagowany przez K. Kosickiego. Chodzi tu o tytuł „Poradnik dla Ludu Górno-Śląskiego", który ukazywał się nie w Niemieckich Piekarach, a w Bytomiu (od 31.01.1851 r.). Periodyk ten drukowany był u znanego drukarza K. Kosickie$\mathrm{go}^{204}$. Pismo miało wymiary $18 \mathrm{~cm} \times 24 \mathrm{~cm}$, pojedynczy egzemplarz liczył 16 stron dwuszpaltowego druku. Był dystrybuowany bezpłatnie w liczbie dochodzącej do 3 tys. egzemplarzy ${ }^{205}$. Treść dwumiesięcznika adresowanego głównie do mieszkańcow wsi zamykała się w szczegółowych informacjach na temat ,istniejących praw i w rozporządzeniach wszelkiego gatunku”, ,wszelkich naukowych przedmiotach, które są każdemu pożyteczne” oraz na ,naukach o gospodarstwie domowym i rolniczym i o lepszych na pewnym naturalnym fundamencie popartych sposobach jego prowadzenia w różnych swoich gałęziach"206. W 1851 r. Kosicki zdołał wydać 6 numerów swego periodyku, który miał się ukazywać aż do końca $1853 \mathrm{r}^{207}$ Trudno przecenić inicjatywę wydawniczą i nakładczą K. Kosickiego, którego leitmoti-

${ }^{201}$ S. 105, nr 578.

${ }_{202}^{02}$ T. Cieślak, Prasa polska na Śląsu, Pomorzu i Mazurach w latach 1832-1870, [w:] Historia prasy polskiej.... s. 271.

${ }^{203}$ T. 1, Mikołów 1920, s. 11-16.

${ }^{304}$ Zob. Leksykon historii Polski, oprac. M. Czajka, M. Kamler, W. Sienkiewicz, Warszawa 1995, s. 1098.

20s Tamże, s. 17.

${ }^{206}$ Zob „Poradnik dla Ludu..." 1851, nr 1.

20: W zasobach archiwalnych Biblioteki Śląskiej w Katowicach znajdują się tylko egzemplarze z $1851 \mathrm{r}$. oraz 2 egzemplarze $z$ następnego roku. Trudno więc zweryfikować datę zaprzestania edycji czasopisma K. Kosickiego. 
vem życiowym była idea udzielania pomocy w przetrwaniu ciężkich chwil, polskiemu społeczeństwu na Górnym Śląsku, uciskanemu przez władze pruskie.

W tej samej Bibliografii polskich czasopism ślqskich (do 1939 roku) pod cytowanym numerem 578. znajduje się informacja jakoby „Poradnik Górno-Śląski” był kontynuowany jako Dodatek i Ciąg Dalszy „Poranika Górmośląskiego”. Z kolei to czasopismo miało być drukowane w Niemieckich Piekarach w 1854 r., a jako nakładcę i w tym przypadku podaje się $\mathrm{K}$. Kosickiego. Tymczasem monumentalne opracowanie pt. Prasa polska w latach 1661-1864, pod redakcją J. Lojka ${ }^{208}$ informuje, że nie chodzi tu o jedno czasopismo pt. „Dodatek i Ciag Dalszy Poradnika Górnośląskiego”, ale o dwa tytuły: „Dodatek Poradniak Górnosląskiego” oraz o „Ciąg Dalszy Poradnika Górnośląskiego”. Nie można jednak potwierdzić tej informacji z tego względu, iż kwerenda archiwalna okazała się bezskuteczna. Niemniej jednak co najmniej dwa lub trzy tytuły wymienionych czasopism prasoznawcy łączą z Piekarami pod Bytomiem.

Wydaje się, że w 1848 r., kiedy ruch polski na Górnym Śląsku po raz pierwszy ukierunkował się na podkreślanie wartości kultury i tradycji, redaktorzy czasopism religijnych i „świeckich" związani z [Niemieckimi] Piekarami budzili, umacniali oraz poszerzali świadomość etniczną, a od 1893 r. - polsko-narodową Gómoślązaków. Dlatego idea narodowa rozwijała się i nabierała mocy, stawiając opór zarówno naciskom germanizacyjnym, jak i propagandzie socjalistycznej oraz tym działaniom, które usiłowały utrudnić jej egzystencję. Potwierdzała także fakt przetrwania polskiego ludu na Górnym Śląsku przy podstawowych dla niego wartościach: wierze ojców i polskości, mimo kilkuwiekowego oderwania od Macierzy ${ }^{209}$. Przyłączenie części Górnego Śląska do Polski w 1922 r. postawiło przed ośrodkami wydawniczymi prasy polskiej w Wielkich Piekarach nowe zadania. Niejako na oczach społeczeństwa zaczął się dokonywać historyczny proces integracji ,idei narodowej $z$ ideą państwa $w$ jedną siłę motoryczną ${ }^{210 "}$. Oczywiście, żaden $\mathrm{z}$ ośrodków wydawniczych $\mathrm{w}$ Piekarch nie potrafił, a nawet nie zamierzał w pełnym zakresie rozwiązać narastających problemów społeczno-narodowych i gospodarczych. Były to bowiem drukarnie małe, nastawione głównie na zaspokojenie konkretnych potrzeb - wręcz egzystencjalnych - społeczności lokalnych. Spośród kilkunastu czasopism polskich de facto związanych $\mathrm{z}$ jedną miejscowością, co w ciągu zaledwie ośmiu dziesięcioleci może stanowić swoisty fenomen edytorski oraz narodowy, kilka z nich (..Dziennik Górnośląski” „Tygodnik Katolicki”, „Gło-

\footnotetext{
2a T. 1. Warseawa 19-6, 5. 2-1.

A. Benisz Gom Slaxt walce o polstasc. Katowice 1930.

$\therefore$ E. Rybarz Polstasc Slasta w hišoncomm romoju, [w:] S. Komar, E. Rybarz, A. Szczepański Garm Slact Mirotow [brw.] 5.94.
} 
sy znad Brynicy”, „Gazeta Piekarska” i - paradoksalnie - „Piekarskie Wiadomości Parafialne") w początkowym okresie bytności na rynku czytelniczym podkreślało ścisły związek tradycji i kultury polskiej (łącznie z językiem narodowym) ze sprawami religii i kościoła na płaszczyźnie narodowych dążeń polskich. Kres polskim wydawnictwom prasowym w Wielkich Piekarach definitywnie położył wybuch II wojny światowej. 